\title{
Catalytic Sulfation of Betulin with Sulfamic Acid: Experiment and DFT Calculation
}

\author{
Aleksandr S. Kazachenko ${ }^{1,2, *(\mathbb{D})}$, Feride Akman ${ }^{3}$, Natalya Yu. Vasilieva ${ }^{1,2}$, Noureddine Issaoui ${ }^{4}$, \\ Yuriy N. Malyar ${ }^{1,2} \mathbb{D}$, Aleksandr A. Kondrasenko ${ }^{2}$, Valentina S. Borovkova ${ }^{1,2} \mathbb{D}$, Angelina V. Miroshnikova 1,2, \\ Anna S. Kazachenko ${ }^{1}$, Omar Al-Dossary ${ }^{5}$ (D), Marek J. Wojcik ${ }^{6}$, Yaroslava D. Berezhnaya ${ }^{2,7}$ \\ and Evgeniy V. Elsuf'ev ${ }^{2}$
}

\section{check for}

Citation: Kazachenko, A.S.; Akman, F.; Vasilieva, N.Y.; Issaoui, N.; Malyar, Y.N.; Kondrasenko, A.A.; Borovkova, V.S.; Miroshnikova, A.V.; Kazachenko, A.S.; Al-Dossary, O.; et al. Catalytic Sulfation of Betulin with Sulfamic Acid: Experiment and DFT Calculation. Int. J. Mol. Sci. 2022 23, 1602. https://doi.org/10.3390/ ijms23031602

Academic Editor: Dongho Kim

Received: 28 December 2021

Accepted: 25 January 2022

Published: 29 January 2022

Publisher's Note: MDPI stays neutral with regard to jurisdictional claims in published maps and institutional affiliations.

Copyright: (C) 2022 by the authors. Licensee MDPI, Basel, Switzerland. This article is an open access article distributed under the terms and conditions of the Creative Commons Attribution (CC BY) license (https:// creativecommons.org/licenses/by/ $4.0 /)$.
1 Department of Organic and Analytical Chemistry, Institute of Nonferrous Metals and Materials Science, Siberian Federal University, pr. Svobodny 79, 660041 Krasnoyarsk, Russia; vasilyeva.nata@mail.ru (N.Y.V.); yumalyar@gmail.com (Y.N.M.); bing0015@mail.ru (V.S.B.); miroshnikova.av@icct.krasn.ru (A.V.M.); kaalla@list.ru (A.S.K.)

2 Institute of Chemistry and Chemical Technology, Krasnoyarsk Scientific Center, Siberian Branch, Russian Academy of Sciences, Akademgorodok, 50, bld. 24, 660036 Krasnoyarsk, Russia;

kondrasenko@icct.ru (A.A.K.); zyppa90298@gmail.com (Y.D.B.); yelsufyevev@gmail.com (E.V.E.)

3 Vocational School of Food, Agriculture and Livestock, University of Bingöl, Bingöl 12000, Turkey; chemakman@gmail.com

4 Laboratory of Quantum and Statistical Physics (LR18ES18), Faculty of Sciences, University of Monastir, Monastir 5079, Tunisia; issaoui_noureddine@yahoo.fr

5 Department of Physics and Astronomy, College of Science, King Saud University, P.O. Box 2455, Riyadh 11451, Saudi Arabia; omar@ksu.edu.sa

6 Faculty of Chemistry, Jagiellonian University, 30-387 Krakow, Poland; wojcik@chemia.uj.edu.pl

7 Institute of Chemical Technologies, Siberian State University of Science and Technology, pr. Mira 82, 660049 Krasnoyarsk, Russia

* Correspondence: leo_lion_leo@mail.ru

Abstract: Betulin is an important triterpenoid substance isolated from birch bark, which, together with its sulfates, exhibits important bioactive properties. We report on a newly developed method of betulin sulfation with sulfamic acid in pyridine in the presence of an Amberlyst ${ }^{\circledR} 15$ solid acid catalyst. It has been shown that this catalyst remains stable when being repeatedly (up to four cycles) used and ensures obtaining of sulfated betulin with a sulfur content of $\sim 10 \%$. The introduction of the sulfate group into the betulin molecule has been proven by Fourier-transform infrared, ultraviolet-visible, and nuclear magnetic resonance spectroscopy. The Fourier-transform infrared (FTIR) spectra contain absorption bands at 1249 and $835-841 \mathrm{~cm}^{-1}$; in the UV spectra, the peak intensity decreases; and, in the nuclear magnetic resonance (NMR) spectra, of betulin disulfate, carbons C3 and C28 are completely shifted to the weak-field region (to 88.21 and $67.32 \mathrm{ppm}$, respectively) with respect to betulin. Using the potentiometric titration method, the product of acidity constants $\mathrm{K}_{1}$ and $\mathrm{K}_{2}$ of a solution of the betulin disulfate $\mathrm{H}^{+}$form has been found to be $3.86 \times 10^{-6} \pm 0.004$. It has been demonstrated by the thermal analysis that betulin and the betulin disulfate sodium salt are stable at temperatures of up to 240 and $220^{\circ} \mathrm{C}$, respectively. The density functional theory method has been used to obtain data on the most stable conformations, molecular electrostatic potential, frontier molecular orbitals, and mulliken atomic charges of betulin and betulin disulfate and to calculate the spectral characteristics of initial and sulfated betulin, which agree well with the experimental data.

Keywords: betulin; sulfation; catalysis; density functional theory (DFT); sulfated betulin

\section{Introduction}

Plant biomass is an important feedstock for a wide range of valuable chemicals [1-5]. Catalytic processing of plant lignocellulosic biomass is an urgent task [6]. Birch biomass can serve as a source of various extractive substances. Birch bark is characterized by a 
particularly high content of extractive substances, which include mono- and triterpenoids, hydrocarbons, alcohols, fatty and resin acids, and phenolic compounds [7-9]

Triterpene compounds represent the most important class of bioactive substances promising for use as pharmaceutical active ingredients, drugs, and phytopreparations [10-17]. The betulin derivatives hold a special place in a triterpenoid series. A rich source of betulin is the Betulaceae family, especially Betula alba, Betula pubescens, Betula platyphylla, and Betula pendula $[12,14,18]$. The betulin content in the birch outer bark ranges within 10-35\%, depending on a type of birch, an area and conditions of its growth, an age of the tree, and other factors [15,18]. In the in vitro and in vivo experiments, betulin and its derivatives exhibit the anti-inflammatory, anticonvulsant, antibacterial, antiviral, anti-HIV, antitumor, and other types of biological activity [11-17,19-23].

Owing to its availability and bioactivity, betulin is well-known as a valuable natural substance, both in its native state and in various modifications. Meanwhile, the low solubility of betulin in water limits its application in medicine, cosmetics, etc. To enhance the water solubility of triterpenoids, different methods are used, including the salt formation, the use of special dosage forms, which ensure the vector delivery of poorly soluble compounds, and nano- and biotechnological techniques $[13,16,17,19,20,24,25]$. The solubility of triterpenoids can be increased via their chemical modification. In particular, the solubility and bioavailability of triterpenoids can be improved by the complexation with $\gamma$-cyclodextrin and other compounds that can form inclusion complexes via the hydrophobic binding $[13,17,19,20,24-27]$. Sulfation of betulin improves its water solubility. Sulfuric esters of betulin and betulinic acid were shown to be bioactive $[27,28]$.

The triterpenoid sulfation methods proposed previously $[28,29]$ are based on the use of sulfuric acid and complexes resulting from the interaction of sulfuric anhydride with pyridine or dimethyl sulfoxide. Thus, the synthesis of betulin disulfate and betulinic acid 3 -sulfate is carried out via sulfation of betulin and betulinic acid with sulfuric acid in pyridine in the presence of acetic anhydride [28].

Sulfation of triterpenoids with chlorosulfonic or sulfamic acid in an environment of weak bases, e.g., dimethylformamide or dioxane, not only can be accompanied by isomerization of initial betulin [23], but the sulfated triterpenoid can be formed initially in a slightly stable $\mathrm{H}$-form [30]. As is known, the sulfur trioxide pyridine complex is a milder sulfating reagent than the $\mathrm{SO}_{3}-1,4$-dioxane complex; it attacks exclusively alcohol groups and does not affect the double bond [31]. The use of pyridine in betulin sulfation instead of 1,4-dioxane and $\mathrm{N}, \mathrm{N}$-dimethylformamide excludes the formation of sulfated betulin in a slightly stable $\mathrm{H}$-form [30]; sulfated betulin has a form of a stable salt.

The aim of this work was to develop a new method for sulfation of betulin with sulfamic acid in the presence of an Amberlyst ${ }^{\circledR} 15$ solid acid catalyst and to examine the reaction products by Fourier-transform infrared ultraviolet-visible (UV-Vis), and nuclear magnetic resonance spectroscopy, thermogravimetric analysis, and X-ray diffraction (XRD) techniques. In addition, the results obtained were theoretically confirmed by the density functional theory method.

\section{Results}

Sulfamic acid is often used for sulfation of natural compounds [32-34]. In the absence of activators, it exhibits a weak activity in the sulfation reactions [35].

In $[33,34,36,37]$, several activators of the process of sulfation of natural polymers with sulfamic acid were proposed: 1,4-dioxane, urea, $\mathrm{N}, \mathrm{N}$-dimethylformamide, morpholine, piperidine, and pyridine. In $[35,38,39]$, urea-based activators of sulfation with sulfamic acid were studied. It was shown that urea has the highest activity. In addition, urea as an activator of the sulfation of components of natural organic raw materials with sulfamic acid was investigated [40-47]. It should be noted that the activating ability of urea and its derivatives in the reactions of sulfation with sulfamic acid can be related to the presence of hydrogen bonds and their number [48-51]. 
The main drawback of the above-mentioned sulfation methods is that the activator cannot be isolated from the reaction mixture for further reuse. In addition, the use of urea as an activator can cause side carbamation reactions $[43,44,52]$, the role of which remains unclear.

In this work, we studied the possibility of betulin sulfation with sulfamic acid in pyridine in the presence of an Amberlyst ${ }^{\circledR} 15$ solid catalyst. The data on the effect of the time of betulin sulfation with sulfamic acid on the sulfur content in the reaction product are given in Table 1. It can be seen that the sulfur content in sulfated betulin increases with the process time.

Table 1. Effect of conditions for the catalytic sulfation of betulin with sulfamic acid in pyridine on the sulfur content in the product.

\begin{tabular}{cccc}
\hline No. & Number of Catalyst Cycles & Time, $\mathbf{h}$ & Sulfur Content, wt $\%$ \\
\hline 1 & 1 & 0.5 & 5,1 \\
2 & 1 & 1.0 & 7,2 \\
3 & 1 & 1.5 & 9.7 \\
4 & 1 & 2.0 & 10.1 \\
5 & 1 & 2.5 & 10.1 \\
6 & 2 & 2.0 & 10.0 \\
7 & 3 & 2.0 & 9.9 \\
8 & 4 & 2.0 & 9.9 \\
\hline
\end{tabular}

In addition, the stability of the catalyst during its repeated use in the process of sulfation of betulin with sulfamic acid was examined. It is noteworthy that the sulfur content in betulin sulfate slightly decreases at the catalyst reuse.

Thus, we can judge about the stability of an Amberlyst- $15^{\circledR}$ catalyst during the catalytic sulfation of betulin with sulfamic acid.

Based on the experimental data obtained, we proposed a scheme for the catalytic sulfation of betulin with sulfamic acid:

$$
\begin{aligned}
& \mathrm{R}-\mathrm{SO}_{3} \mathrm{H}+\mathrm{SO}_{3} \cdot \mathrm{NH}_{3} \rightarrow \mathrm{R}-\mathrm{SO}_{3}-\mathrm{NH}_{4}{ }^{+}+\mathrm{SO}_{3}{ }^{-} \\
& \mathrm{SO}_{3}+\text { pyridine } \rightarrow \mathrm{SO}_{3} \text { * pyridine } \\
& \mathrm{SO}_{3}{ }^{*} \text { pyridine (sulfating complex) }+\mathrm{R}^{\prime}-(\mathrm{OH})_{2} \rightarrow \mathrm{R}^{\prime}-\left(\mathrm{O}-\mathrm{SO}_{3} \mathrm{H}\right)_{2}+\text { pyridine } \\
& \mathrm{R}^{\prime}-\left(\mathrm{O}-\mathrm{SO}_{3} \mathrm{H}\right)_{2}+\mathrm{R}-\mathrm{SO}_{3} \mathrm{NH}_{4} \rightarrow \mathrm{R}^{\prime}-\left(\mathrm{O}-\mathrm{SO}_{3} \mathrm{NH}_{4}\right)_{2}+\mathrm{R}-\mathrm{SO}_{3} \mathrm{H},
\end{aligned}
$$

where $\mathrm{R}$ is the catalyst matrix and $\mathrm{R}^{\prime}$ is the betulin molecule.

It was shown in [53] that sulfamic acid can be in the zwitterionic form and, in the presence of organic bases, can form a donor-acceptor complex, which will be more active in the sulfation reactions $[54,55]$.

According to the scheme proposed by us, during the catalytic sulfation of betulin, first, the sorption of the zwitterionic form of sulfamic acid on the catalyst matrix occurs, which is followed by decomposition of the acid into sulfur trioxide and ammonia, and sulfur trioxide interacts with 1,4-dioxane with the formation of a sulfating complex. The sulfating complex sulfates betulin and removes sulfur trioxide. This is followed by the exchange by ammonium cations between the catalyst matrix and the acidic form of betulin sulfate.

\subsection{Fourier-Transform Infrared Spectroscopy Study}

The introduction of the sulfate group into the betulin molecule was confirmed by IR spectroscopy (Figure 1). 


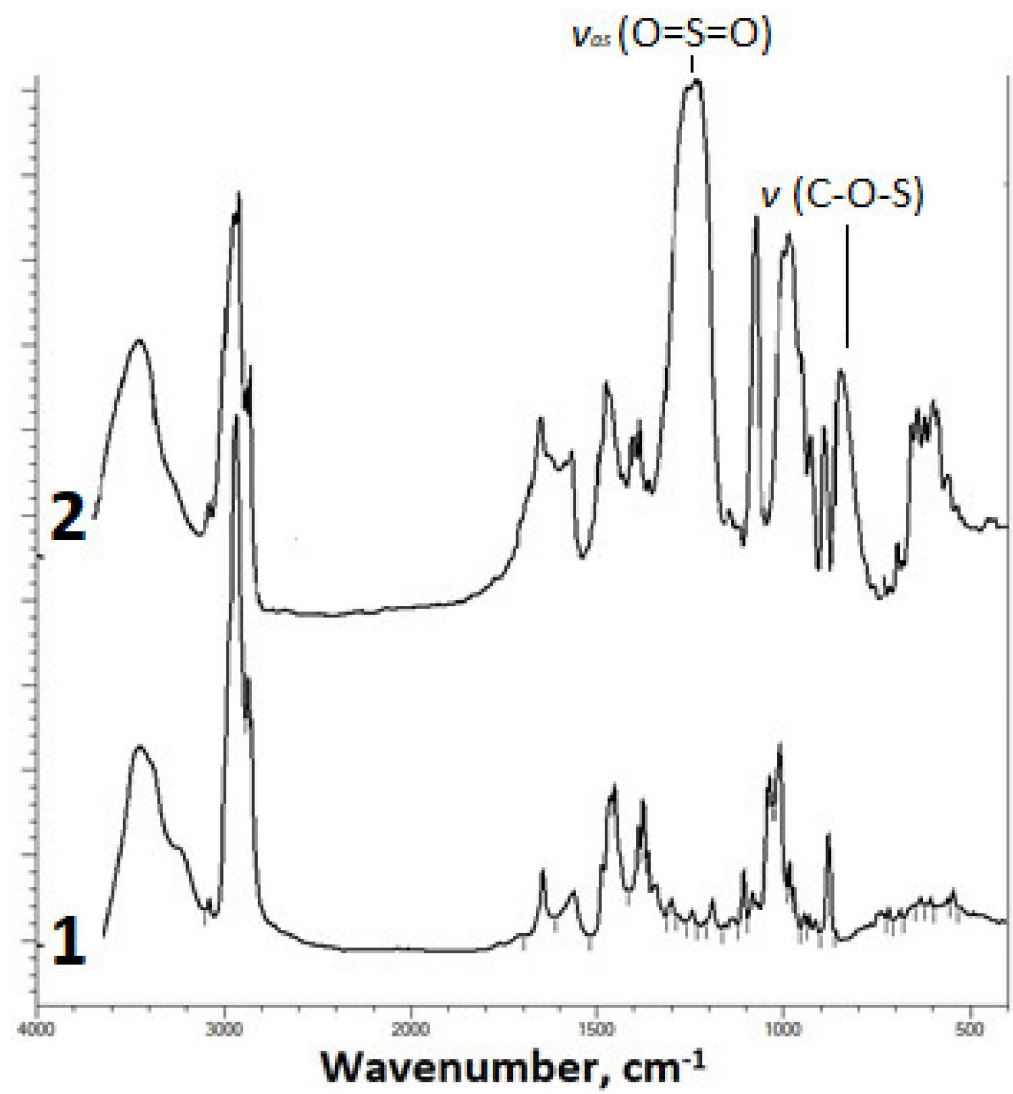

Figure 1. FTIR spectra of (1) betulin and (2) sulfated betulin in the sodium form.

The FTIR spectrum of the betulin disulfate sodium salt contains, along with the absorption bands characteristic of the initial betulin, a high-intensity band of asymmetric stretching vibrations $v_{\text {as }}(\mathrm{O}=\mathrm{S}=\mathrm{O})$ at $1249 \mathrm{~cm}^{-1}$ and an absorption band of stretching vibrations $v(\mathrm{C}-\mathrm{O}-\mathrm{S})[56,57]$ in the range of $835-841 \mathrm{~cm}^{-1}$.

\subsection{Ultraviolet-Visible Spectroscopy Study}

The initial and sulfated betulin was examined by UV-Vis spectroscopy (Figure 2).

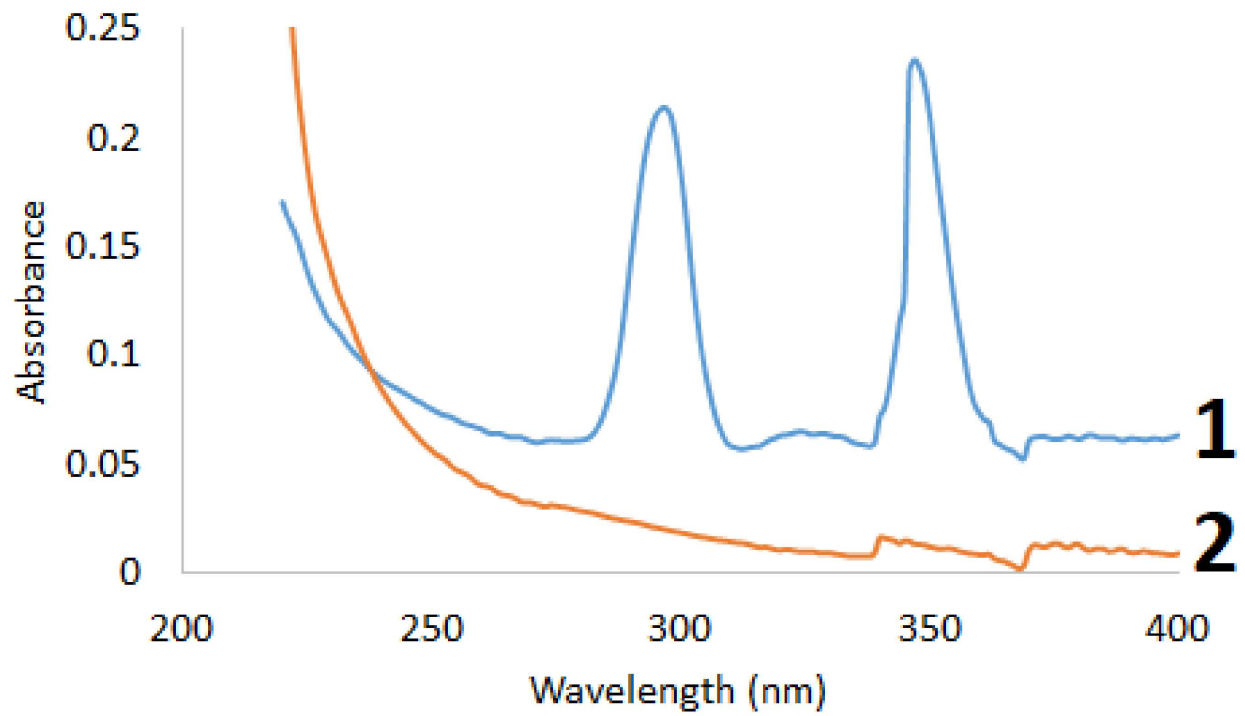

Figure 2. UV spectra of (1) betulin and (2) sulfated betulin. 
To qualitatively identify the presence of sulfo groups in the betulin sulfation products, the electronic absorption spectra in the range of $220-400 \mathrm{~nm}$ were reproduced in the alcohol solution. It can be seen in Figure 2 that the UV spectra of the initial and sulfated betulin have different profiles, which is indicative of the presence of new functional groups in the sulfated products [58]. A factor indicating the introduction of a sulfo group into the betulin structure is a decrease in the total intensity of the sulfation products. The introduction of an additional functional group with an increase in the average molecular weight leads to a decrease in the intensity in the UV range.

\subsection{Nuclear Magnetic Resonance Study}

The composition and structure of the betulin disulfate sodium salt was confirmed by ${ }^{13} \mathrm{C}$ NMR spectroscopy. According to the literature data [59], the chemical shift of the secondary C3 carbon atom bonded to the hydroxyl group is observed at 78-79 ppm and the chemical shift of the primary C28 carbon atom, at 59-60 ppm. An analysis of the ${ }^{13} \mathrm{C}$ NMR spectra of the initial betulin and the betulin disulfate sodium salt showed that the chemical shift of the C3 carbon atom in the initial betulin is observed at $78.25 \mathrm{ppm}$ and the chemical shift of the C28 carbon atom, at $58.96 \mathrm{ppm}$. In the synthesized betulin disulfate, the chemical shifts of the C3 and C28 carbons in comparison with betulin are completely shifted to the low-field region (to 88.21 and $67.32 \mathrm{ppm}$, respectively). This proves the complete replacement of the betulin hydroxyl groups by the sulfate.

\subsection{X-Ray Diffraction Study}

The initial betulin and betulin sulfate were analyzed by X-ray diffractometry (Figure 3). The initial betulin has a crystalline structure with the high-intensity bands [60]. During sulfation, a decrease in the crystallinity of betulin is observed, as is the case with its chemical modification by other methods [61].

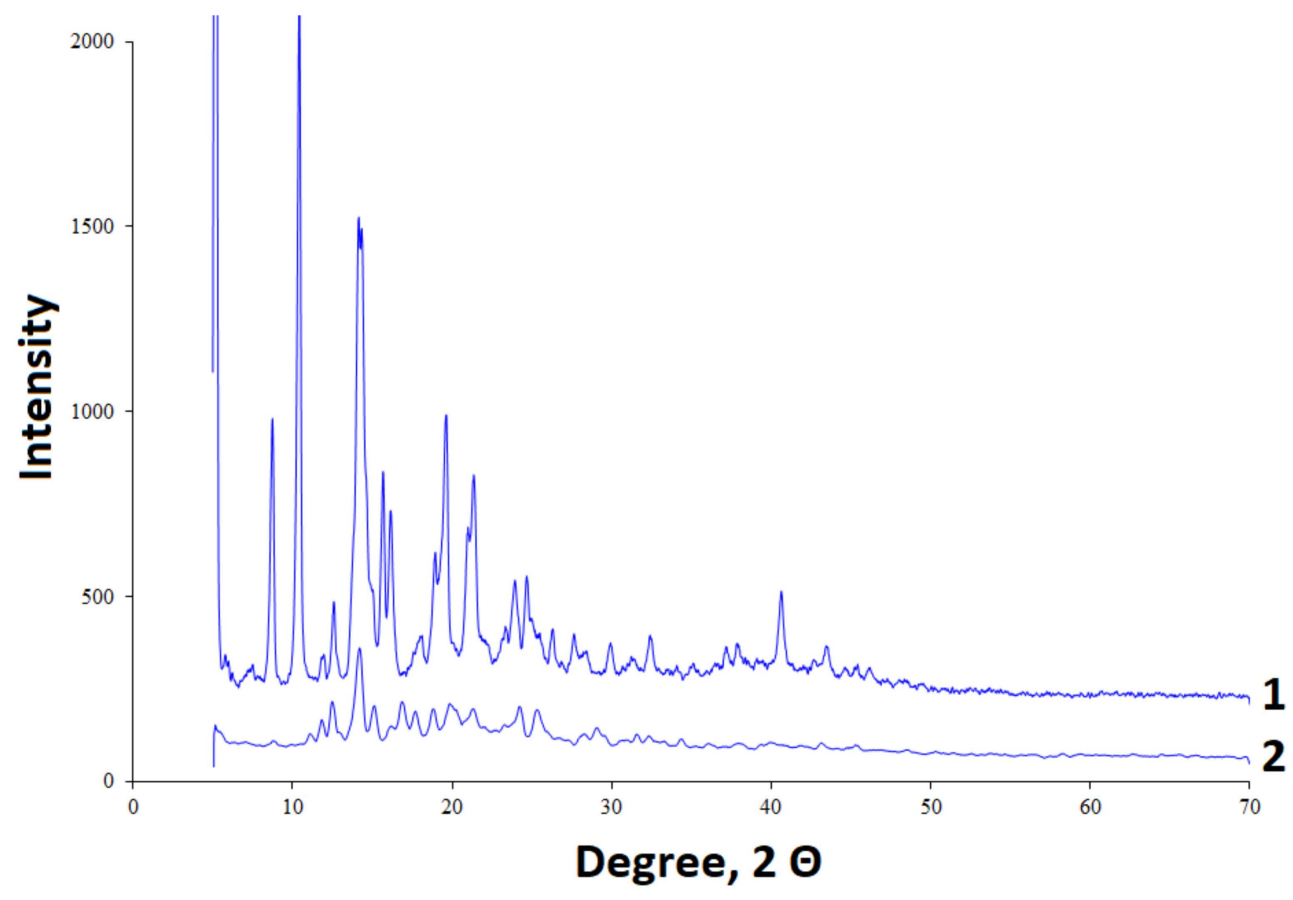

Figure 3. XRD diffraction patterns of (1) betulin and (2) betulin sulfate.

\subsection{Thermal Analysis}

Figure 4 shows a thermogram of betulin and the betulin disulfate sodium salt obtained upon heating in the argon atmosphere. 


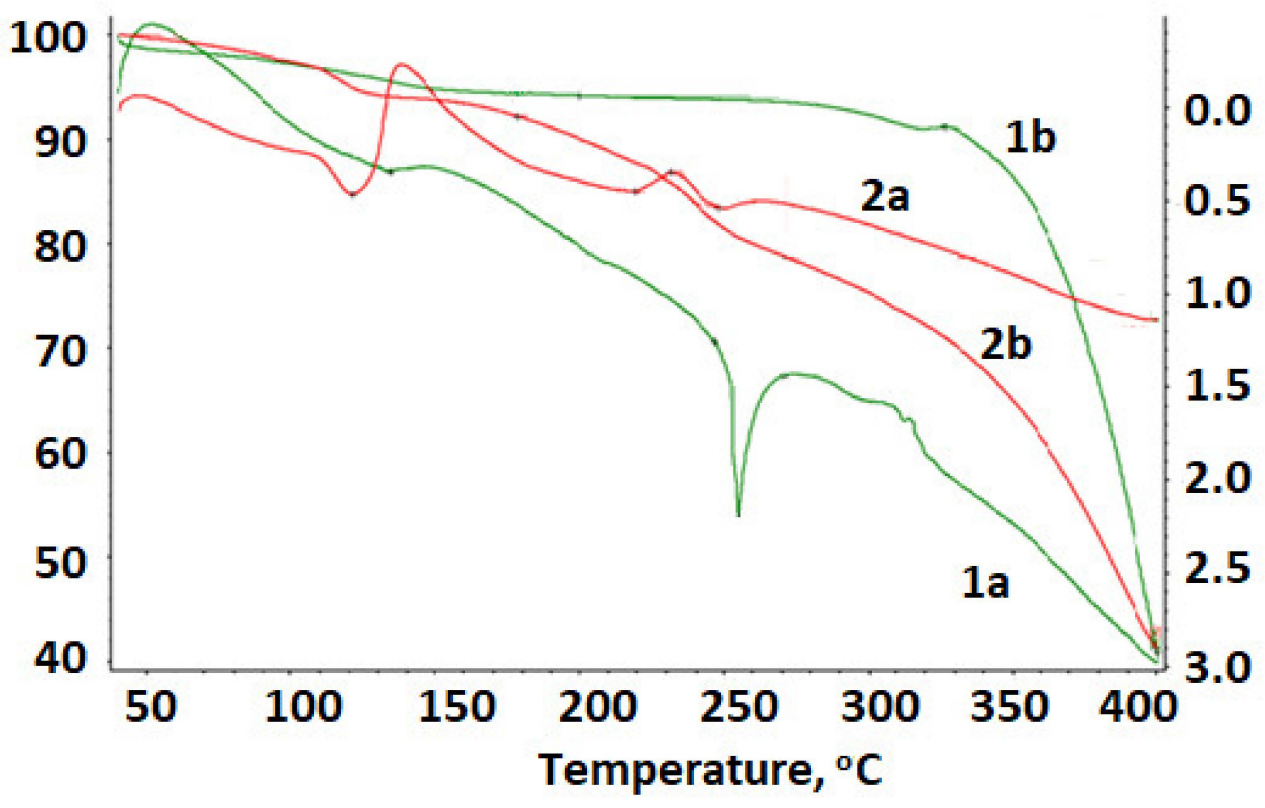

Figure 4. Thermogram of (1) betulin and (2) betulin disulfate sodium salt: (a) DTA and (b) TG curves.

The temperature dependence of the weight loss (the TG curve) for betulin has a plateau; the horizontal section is indicative of the stability of the chemical compound in the investigated temperature range at the absence of chemical transformations. A vertical step in the curve is indicative of the chemical decomposition of the material [62].

At a temperature of $134.5^{\circ} \mathrm{C}$, a loss of water contained in betulin is observed. The weight loss is $5.83 \%$. The TG curve reflects an intense loss in the sample mass above $260^{\circ} \mathrm{C}$.

To determine the transformation temperatures more accurately, a differential notation was used. A peak in the DTA curve in the range of $240-260{ }^{\circ} \mathrm{C}$ is indicative of a phase transformation in betulin, which is accompanied by the endothermic effect. This is a firstorder phase transition; in this region, betulin melts with the subsequent decomposition.

In contrast to initial betulin, in the betulin disulfate sodium salt the water loss occurs earlier and the weight loss is $7.76 \%$.

In the DTA curve at temperatures of $220-230{ }^{\circ} \mathrm{C}$, the exothermic effect is reflected, which corresponds to the decomposition of the betulin disulfate sodium salt, apparently with the $\mathrm{SO}_{2}$ release. The weight loss is $15.5 \%$, according to the sulfur content in betulin disulfate. The degree of decomposition of betulin disulfate with the $\mathrm{SO}_{2}$ release in this region is $79 \%$, which is consistent with the data reported in $[43,55,63]$. We can state that betulin and the betulin disulfate sodium salt are stable at temperatures of up to 240 and $220^{\circ} \mathrm{C}$, respectively.

\subsection{Acidity Constants}

In this work, the product of acidity constants $K_{1}$ and $K_{2}$ of the solution of the betulin disulfate $\mathrm{H}^{+}$form was determined by a potentiometric titration (Figure 5). The average product of the first and second dissociation constants $\mathrm{K}_{1}$ and $\mathrm{K}_{2}$ was found to be $3.86 \times 10^{-6} \pm 0.004$. Figure 5 shows the dependence of $\mathrm{pH}$ of the solution of the betulin disulfate $\mathrm{H}^{+}$form on the sodium hydroxide volume.

Since the titration curve contains only one jump, it is obvious that the $\mathrm{H}^{+}$form of betulin disulfate has similar values of the first and second dissociation constants $\mathrm{K}_{1}$ and $\mathrm{K}_{2}$. This, most likely, originates from the betulin disulfate structure, in which sulfate groups are distant from each other. 


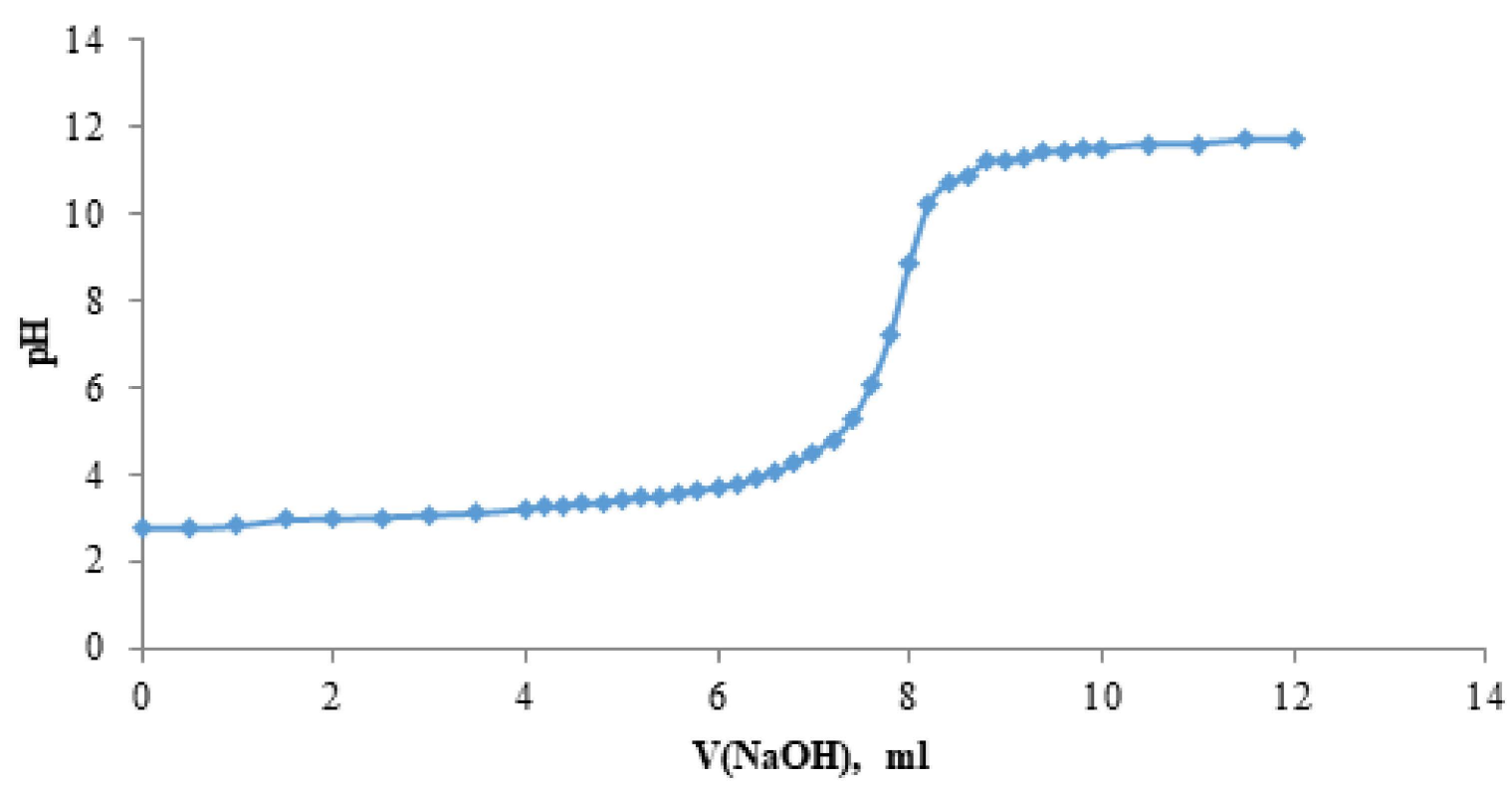

Figure 5. Dependence of $\mathrm{pH}$ of the solution of the $\mathrm{H}+$ form of betulin disulfate on the sodium hydroxide volume.

This conclusion does not contradict the data on dissociation constants of the known dicarboxylic acids with carboxyl groups significantly distant from each other [64]; therefore, for example, in adipic acid, the $\mathrm{K}_{1}$ and $\mathrm{K}_{2}$ values are of the same order of magnitude: $3.7 \times 10^{-5}$ and $1.93 \times 10^{-5}$, respectively.

According to the obtained acidity constant, the $\mathrm{H}^{+}$form of betulin disulfate is an acid stronger than carboxylic acids, but weaker than sulfonic acids. Basing on the determined constant, the $\mathrm{H}+$ form of betulin disulfate was confirmed, which can be obtained by adding a mineral acid salt to the aqueous solution.

\subsection{Theoretical Calculations}

\subsubsection{Optimized Geometry and MEP Analysis of Betulin and Betulin Disulfate}

The primary task of the quantum chemical calculations is to determine the optimized geometry of a molecule [65-67]. The optimized geometry of betulin and betulin disulfate was calculated using the CAM-B3LYP/6-31 + G(d,p) method. The data obtained are presented in Figure 6, where BE is betulin and BES is betulin disulfate.

To estimate the positions of electrophilic and nucleophilic actions, as well as interactions of hydrogen bonds, the MEP was calculated, which, in turn, is related to the electron density and extremely useful $[68,69]$. For this purpose, MEP maps of betulin and betulin disulfate were built, which helped us to estimate the regions of nucleophilic and electrophilic attacks and the interaction of hydrogen bonds. The MEP surfaces of betulin and disulfated betulin were determined by the CAM-B3LYP/6-31+G(d,p) method used for optimizing molecules. The three-dimensional surface maps are shown in Figure 7.

In the MEP analysis, the reactive regions are marked by different color codes corresponding to the electrostatic potential color order, e. g., red <orange <yellow <green $<$ blue. In the MEP maps, the blue color indicates an electron-deficient area, which has a positive electrostatic potential, and the red color indicates an electron-rich area, which has a negative electrostatic potential. The green color in the MEP maps corresponds to a neutral region with zero electrostatic potential $[44,70]$. 
a) $\mathrm{BE}$

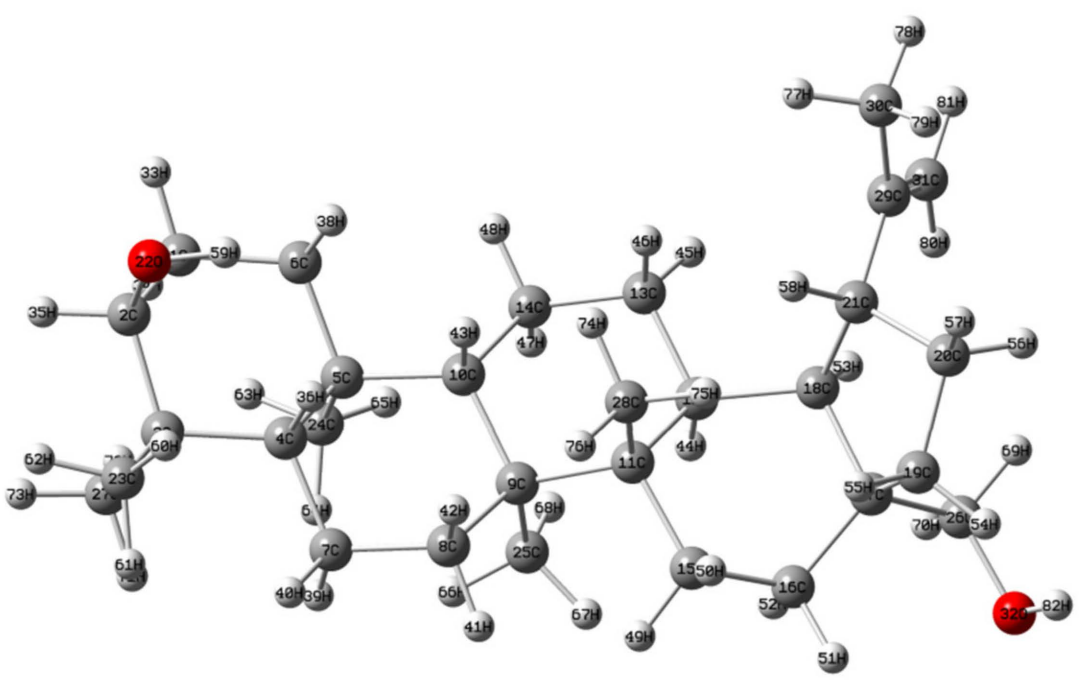

b) BES

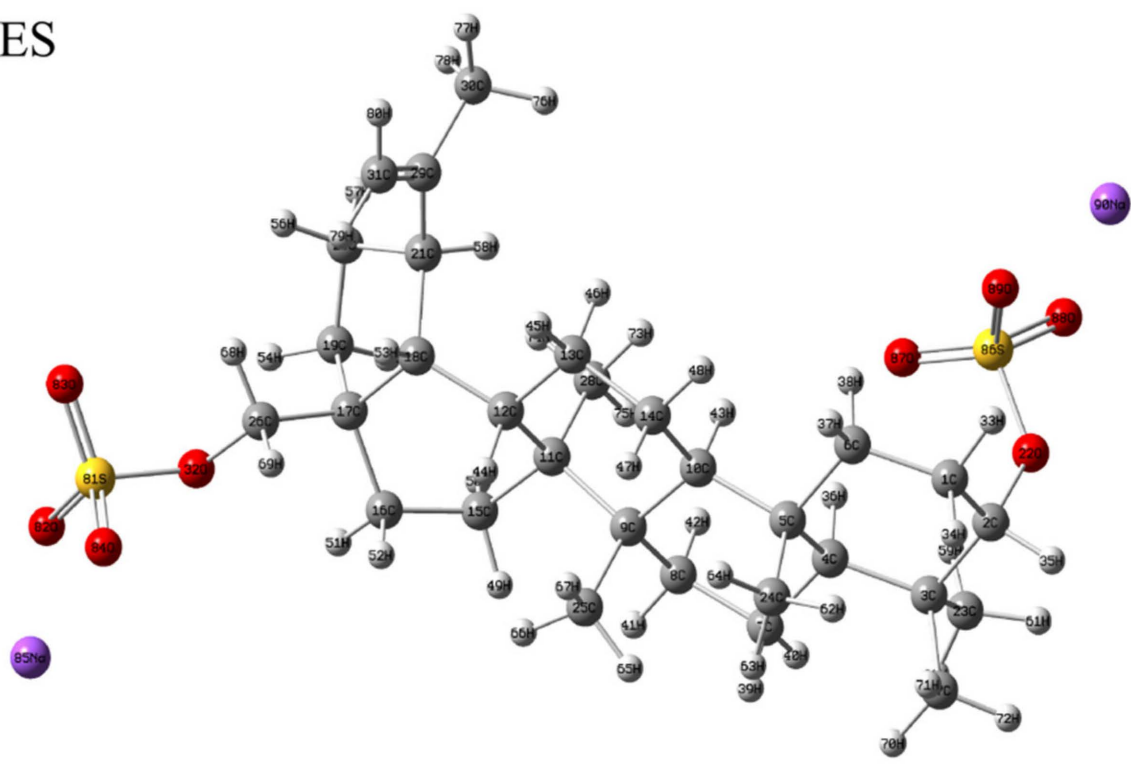

Figure 6. Geometrical structures of (a) betulin and (b) sulfated betulin optimized by the CAMB3LYP/6-31 + G(d, p) level of theory.

As can be seen in Figure 7a, hydrogen atoms attached to oxygen atoms have the lowest electron density and are colored in blue in the map, while the electron density of oxygen atoms is higher, which is reflected by the red color. For betulin disulfate, the picture is different. After the introduction of sulfate groups in the 3 and 28 betulin sites and their stabilization with sodium cations, the MEP maps change. In Figure 7b, the blue color in the betulin disulfate MEP maps is observed mainly above the sodium atoms. In addition, the hydrogen atoms attached to oxygen in the betulin molecule change for the sulfate, the electron density on the oxygen atoms decreases, and the red color changes for yellow and greenish-yellow. A similar phenomenon was observed previously in $[40,41,44]$. 


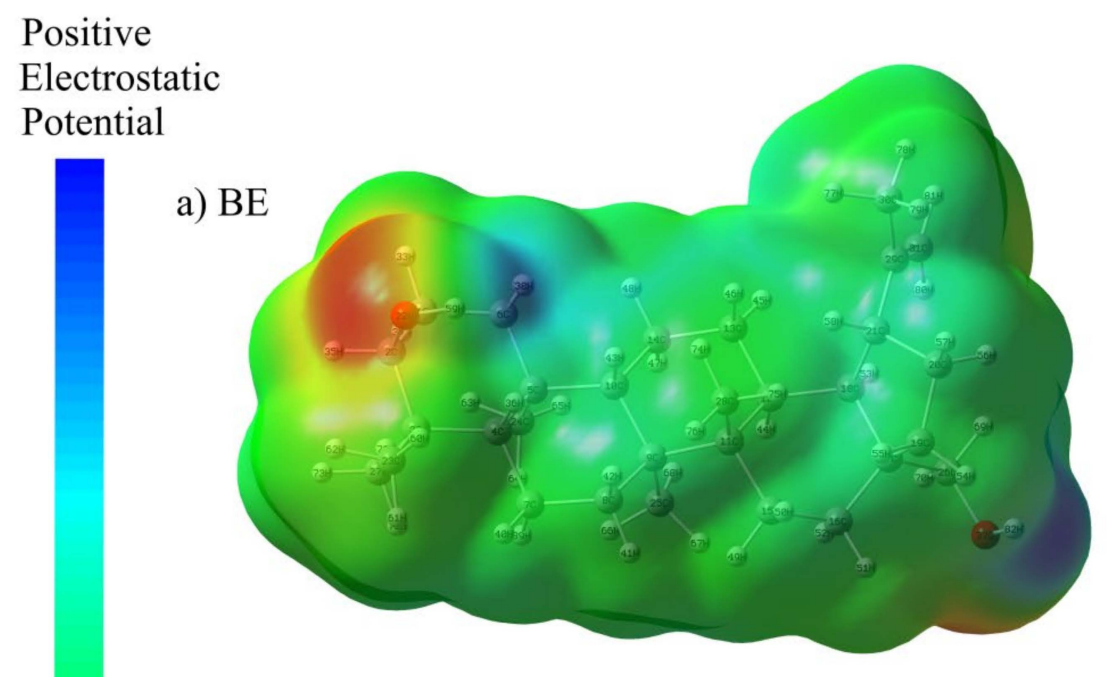

b) BES

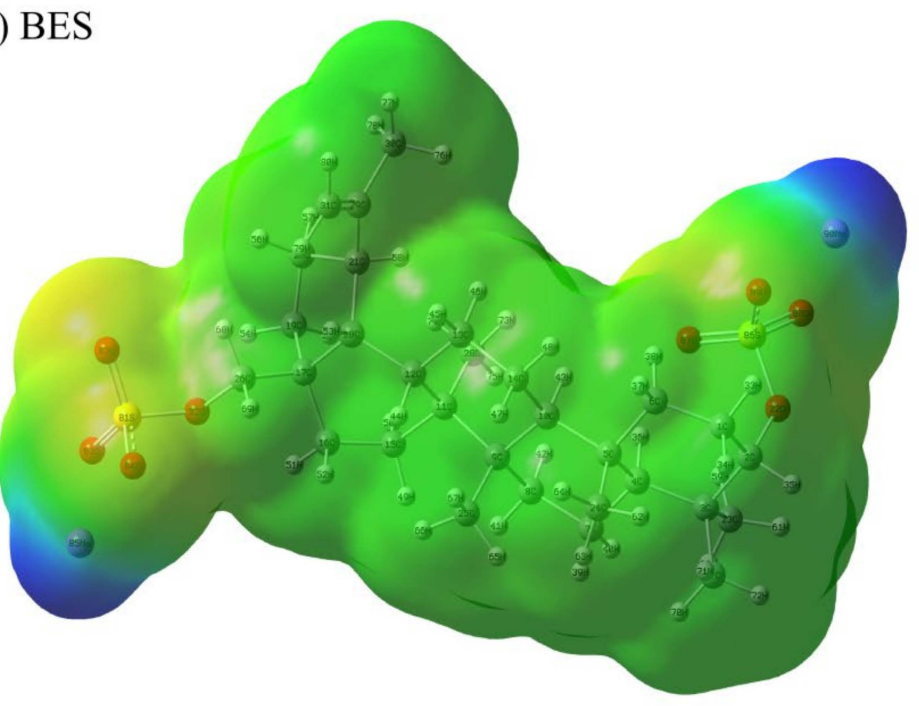

Negative

Electrostatic

Potential

Figure 7. MEP surfaces of (a) betulin and (b) sulfated betulin built using the CAM-B3LYP/6-31 + G $(\mathrm{d}, \mathrm{p})$ level of theory.

\subsubsection{HOMO_LUMO Analysis and Calculated Electronic Properties}

The highest occupied molecular orbital (HOMO) and the lowest unoccupied molecular orbital (LUMO) and their respective energies $\mathrm{E}_{\mathrm{HOMO}}$ and $\mathrm{E}_{\mathrm{LUMO}}$ are important for obtaining data on the structure and reactivity of substances. The HOMO and LUMO are called the frontier molecular orbital (FMOs) because they can determine the interaction of a molecule with other species.

The HOMO is defined as a nucleophile that donates an electron (donor) and the LUMO, as an electrophile that receives an electron from a nucleophile (acceptor) [69,71,72]. A molecule with a narrow band gap suggests the high polarization and is related mainly to the high chemical reactivity and low kinetic stability. The HOMO and LUMO of betulin and betulin disulfate calculated by the CAM-B3LYP/6-31 + G (d, p) method are plotted in Figure $8 \mathrm{a}, \mathrm{b}$, respectively. 

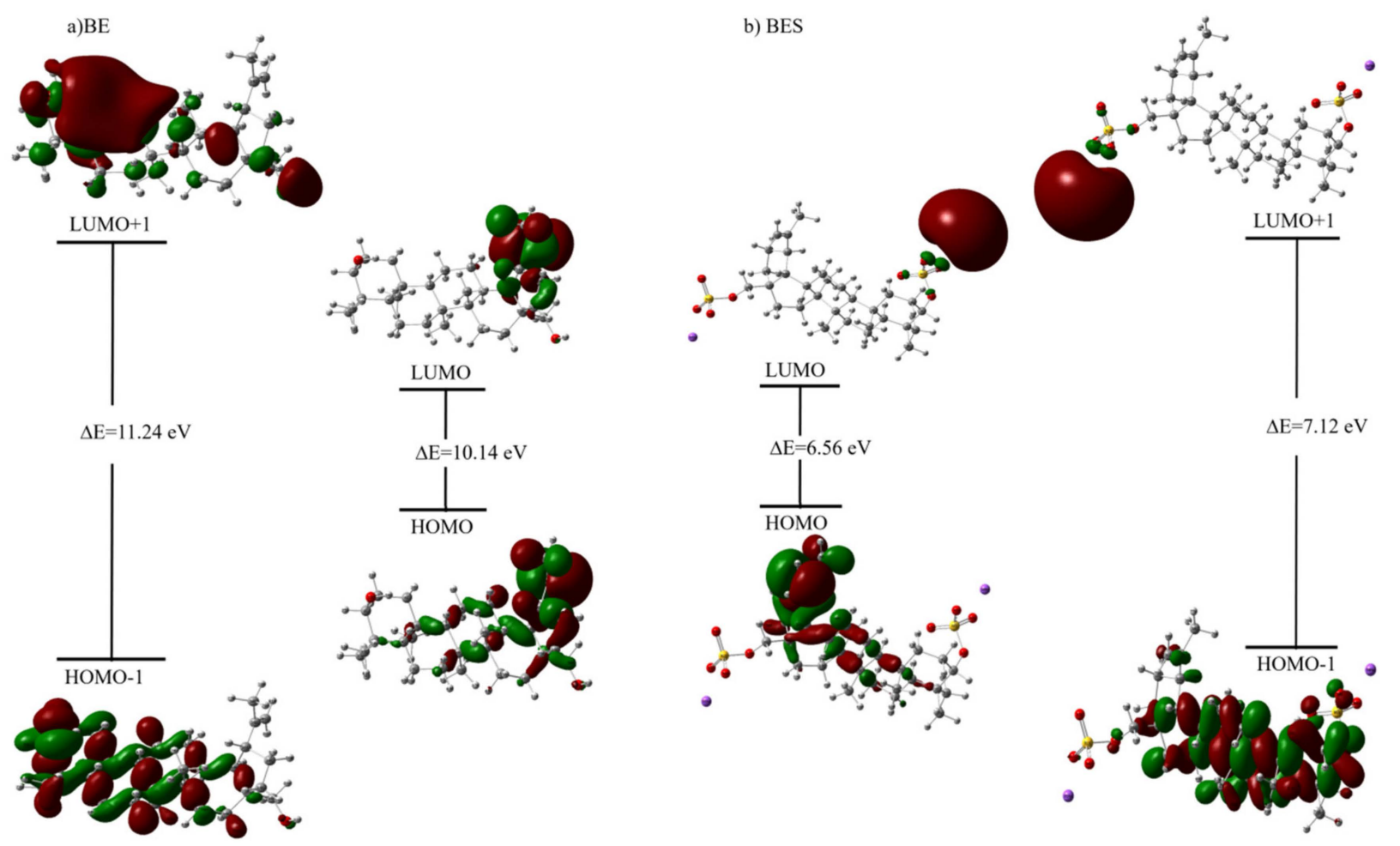

Figure 8. Molecular orbital diagrams of (a) betulin and (b) sulfated betulin built using the CAMB3LYP/6-31 + G (d, p) level of theory.

It can be seen in Figure 8 that, during betulin sulfation, the energy gap narrows by $3.5 \mathrm{eV}$ on average, which may be indicative of a higher reactivity of betulin disulfate in comparison with the initial botulin

Basing on the HOMO-LUMO energy gap, nucleophilic index (N), optical softness $\left(\sigma_{\mathrm{o}}\right)$, electronegativity $(\chi)$, electron affinity $(\mathrm{A})$, chemical potential $(\mu)$, ionization energy $(\mathrm{I})$, hardness $(\eta)$, softness $(\varsigma)$, electrophilicity index $(\omega)$, and maximum charge transfer index $\left(\Delta \mathrm{N}_{\max }\right)$ were calculated (Table 2$)[73-75]$ using the equations

$$
\begin{gathered}
\mathrm{I}=-\mathrm{E}_{\mathrm{HOMO}} \\
\mathrm{A}=-\mathrm{E}_{\mathrm{LUMO}} \\
\chi=-\frac{1}{2}\left(\mathrm{E}_{\mathrm{LUMO}}+\mathrm{E}_{\mathrm{HOMO}}\right) \\
\frac{\mu=1}{2}\left(\mathrm{E}_{\mathrm{LUMO}}+\mathrm{E}_{\mathrm{HOMO}}\right) \\
\frac{\eta=1}{2}\left(\mathrm{E}_{\mathrm{LUMO}}-\mathrm{E}_{\mathrm{HOMO}}\right) \\
\zeta=\frac{1}{\eta} \\
\omega=\frac{\mu^{2}}{2 \eta} \\
\Delta \mathrm{Nmax}^{2}=-\frac{\mu}{\eta} \\
\mathrm{N}=\frac{1}{\omega} \\
\sigma_{\mathrm{O}}=\frac{1}{\mathrm{E}_{\mathrm{g}}}
\end{gathered}
$$


Table 2. Some electronic properties of betulin (BE) and betulin sulfate (BES) at the CAM-B3LYP and B3LYP / 6-31+G (d, p) level of theory.

\begin{tabular}{|c|c|c|c|c|}
\hline \multirow[t]{2}{*}{ Parameter $(\mathrm{eV})$} & \multicolumn{2}{|c|}{ BE } & \multicolumn{2}{|c|}{ BES } \\
\hline & CAM-B3LYP & B3LYP & CAM-B3LYP & B3LYP \\
\hline $\mathrm{E}_{\mathrm{HOMO}}$ & -8.0636 & -6.4970 & -7.6140 & -6.0592 \\
\hline $\mathrm{E}_{\mathrm{LUMO}}$ & 2.0841 & 0.6027 & -1.0534 & -1.7704 \\
\hline $\begin{array}{c}\text { Energy band gap } 1\left(\Delta \mathrm{E}_{1}=\right. \\
\left.\mathrm{E}_{\mathrm{LUMO}}-\mathrm{E}_{\mathrm{HOMO}}\right)\end{array}$ & 10.1477 & 7.0997 & 6.5607 & 4.2888 \\
\hline $\mathrm{E}_{\mathrm{HOMO}-1}$ & -8.3901 & -6.7860 & -8.0834 & -6.5468 \\
\hline $\mathrm{E}_{\mathrm{LUMO}+1}$ & 2.8428 & 1.5094 & -0.9562 & -1.6803 \\
\hline $\begin{array}{l}\text { Energy band gap } 2\left[\Delta \mathrm{E}_{2}=\right. \\
\left.\left(\mathrm{E}_{\mathrm{LUMO}+1}\right)-\left(\mathrm{E}_{\mathrm{HOMO}-1}\right)\right]\end{array}$ & 11.2329 & 8.2954 & 7.1272 & 4.8665 \\
\hline Chemical potential $(\mu)$ & -2.9897 & -2.9471 & -4.3337 & -3.9148 \\
\hline Softness $(\varsigma)$ & 0.1971 & 0.2817 & 0.3048 & 0.4663 \\
\hline Ionization energy (I) & 8.0636 & 6.4970 & 7.6140 & 6.0592 \\
\hline Electron affinity (A) & -2.0841 & -0.6027 & 1.0534 & 1.7704 \\
\hline Electronegativity $(x)$ & 2.9897 & 2.9471 & 4.3337 & 3.9148 \\
\hline Chemical hardness $(\eta)$ & 5.0738 & 3.5499 & 3.2803 & 2.1444 \\
\hline Electrophilicity index $(\omega)$ & 0.8808 & 1.2234 & 2.8626 & 3.5734 \\
\hline $\begin{array}{l}\text { Maximum charge transfer } \\
\text { index }\left(\Delta \mathrm{N}_{\max }\right)\end{array}$ & 0.5892 & 0.8302 & 1.3211 & 1.8256 \\
\hline Nucleophilic index (N) & 1.1353 & 0.8174 & 0.3493 & 0.2798 \\
\hline Optical softness $\left(\sigma_{\mathrm{o}}\right)$ & 0.0985 & 0.1409 & 0.1524 & 0.2332 \\
\hline
\end{tabular}

The low kinetic stability and high biological activity, polarizability, and chemical reactivity are indicated by the narrow HOMO-LUMO band gap [76].

The negative values of the chemical potential of molecules suggest that these molecules are stable. The electrophilic index provides information on the ability of a molecule to bind to biomolecules [77]. According to [78], weak electrophiles have an electrophilicity index of $\omega<0.8 \mathrm{eV}$; moderate electrophiles, $0.8<\omega<1.5 \mathrm{eV}$; and strong electrophiles, $\omega>1.5 \mathrm{eV}$. In the betulin sulfation process, the electrophilic effect is enhanced, as indicated by an increase in the electrophilicity index from 0.8808 to $2.8626 \mathrm{eV}$ in the CAM-B3LYP method and from 1.2234 to $3.5734 \mathrm{eV}$ in the B3LYP method.

It should be noted that, in the CAM-B3LYP and B3LYP calculations, the introduction of sulfate groups into the betulin molecule leads to a decrease in the chemical potential $\mu$ from -2.9897 to $-4.3337 \mathrm{eV}$ and from -2.9471 to $-3.9148 \mathrm{eV}$; in the ionization energy I from 8.0636 to $7.6140 \mathrm{eV}$ and from 6.4970 to $6.0592 \mathrm{eV}$; in the chemical hardness $\eta$ from 5.0738 to $3.2803 \mathrm{eV}$ and from 3.5499 to $2.1444 \mathrm{eV}$; in the nucleophilic index $\mathrm{N}$ from 1.1353 to $0.3493 \mathrm{eV}$ and from 0.8174 to $0.2798 \mathrm{eV}$; as well as to an increase in softness $\varsigma$ from 0.1971 to $0.3048 \mathrm{eV}$ and from 0.2817 to $0.4663 \mathrm{eV}$; in the electron affinity EA from -2.0841 to $1.0534 \mathrm{eV}$ and from -0.6027 to $1.7704 \mathrm{eV}$; in the electronegativity $\chi$ from 2.9897 to $4.3337 \mathrm{eV}$ and from 2.9471 to $3.9148 \mathrm{eV}$; in the maximum charge transfer index $\Delta \mathrm{N}_{\max }$ from 0.5892 to $1.3211 \mathrm{eV}$ and from 0.8302 to $1.8256 \mathrm{eV}$; and in the optical softness $\sigma_{\mathrm{o}}$ from 0.0985 to $0.1524 \mathrm{eV}$ and from 0.1409 to $0.2332 \mathrm{eV}$, respectively (Table 2).

\subsubsection{Mulliken Atomic Charges}

The Mulliken atomic charges play an important role in the use of quantum-chemical calculations as applied to a molecular system for determining its dipole moment, electronic structure, molecular polarizability, atomic charge effect, and many other characteristics $[70,79,80]$. These charges are expected to affect the electronic parameters, refraction, dipole moment, and polarizability. The Mulliken atomic charges of the initial betulin and its sulfate in the B3LYP / 6-31G + $(d, p)$ and CAM-B3LYP / 6-31G $+(d, p)$ methods are given in Table 3. The positive charges are localized on sulfur and hydrogen atoms and the negative ones, on oxygen; for carbon atoms there are both the positive and negative charges. 
Table 3. Mulliken atomic charges of betulin (BE) and betulin sulfate (BES) at the CAM-B3LYP and B3LYP / 6-31+G (d, p) levels of theory.

\begin{tabular}{|c|c|c|c|c|c|c|c|}
\hline \multicolumn{4}{|c|}{ BE } & \multicolumn{4}{|c|}{ BES } \\
\hline Label & Symbol & CAM-B3LYP & B3LYP & Label & Symbol & CAM-B3LYP & B3LYP \\
\hline 1 & $\mathrm{C}$ & -0.20309 & -0.2021 & 1 & $\mathrm{C}$ & -0.22973 & -0.22872 \\
\hline 2 & $\mathrm{C}$ & 0.18481 & 0.18906 & 2 & $\mathrm{C}$ & 0.18324 & 0.18934 \\
\hline 3 & $\mathrm{C}$ & 0.01401 & 0.01816 & 3 & $\mathrm{C}$ & 0.00964 & 0.01468 \\
\hline 4 & $\mathrm{C}$ & -0.05888 & -0.0508 & 4 & $\mathrm{C}$ & -0.07512 & -0.06891 \\
\hline 5 & $\mathrm{C}$ & 0.05783 & 0.05865 & 5 & $\mathrm{C}$ & 0.05565 & 0.05635 \\
\hline 6 & $\mathrm{C}$ & -0.20435 & -0.19927 & 6 & $\mathrm{C}$ & -0.20148 & -0.19788 \\
\hline 7 & $\mathrm{C}$ & -0.19031 & -0.19141 & 7 & $\mathrm{C}$ & -0.19045 & -0.1918 \\
\hline 8 & $\mathrm{C}$ & -0.1909 & -0.19068 & 8 & $\mathrm{C}$ & -0.19249 & -0.19222 \\
\hline 9 & $\mathrm{C}$ & 0.04579 & 0.04836 & 9 & $\mathrm{C}$ & 0.04544 & 0.04774 \\
\hline 10 & $\mathrm{C}$ & -0.06271 & -0.0556 & 10 & $\mathrm{C}$ & -0.07765 & -0.06991 \\
\hline 11 & $\mathrm{C}$ & 0.07032 & 0.07734 & 11 & $\mathrm{C}$ & 0.06934 & 0.07627 \\
\hline 12 & $\mathrm{C}$ & -0.06643 & -0.06291 & 12 & $\mathrm{C}$ & -0.0649 & -0.06222 \\
\hline 13 & $\mathrm{C}$ & -0.18767 & -0.18994 & 13 & $\mathrm{C}$ & -0.18787 & -0.19012 \\
\hline 14 & $\mathrm{C}$ & -0.19296 & -0.19412 & 14 & $\mathrm{C}$ & -0.19225 & -0.19329 \\
\hline 15 & $\mathrm{C}$ & -0.21532 & -0.2128 & 15 & $\mathrm{C}$ & -0.21202 & -0.20973 \\
\hline 16 & $\mathrm{C}$ & -0.17216 & -0.17377 & 16 & $\mathrm{C}$ & -0.18315 & -0.18554 \\
\hline 17 & $\mathrm{C}$ & 0.01376 & 0.02268 & 17 & $\mathrm{C}$ & $-6.45 \mathrm{E}-4$ & 0.00905 \\
\hline 18 & $\mathrm{C}$ & -0.07535 & -0.07321 & 18 & $\mathrm{C}$ & -0.07845 & -0.07622 \\
\hline 19 & $\mathrm{C}$ & -0.19513 & -0.19369 & 19 & $\mathrm{C}$ & -0.1947 & -0.1942 \\
\hline 20 & $\mathrm{C}$ & -0.18731 & -0.18628 & 20 & $\mathrm{C}$ & -0.19282 & -0.1934 \\
\hline 21 & $\mathrm{C}$ & -0.11263 & -0.11347 & 21 & $\mathrm{C}$ & -0.11335 & -0.11266 \\
\hline 22 & $\mathrm{O}$ & -0.56017 & -0.55848 & 22 & $\mathrm{O}$ & -0.57467 & -0.58 \\
\hline 23 & $\mathrm{C}$ & -0.29325 & -0.29311 & 23 & $\mathrm{C}$ & -0.30288 & -0.30325 \\
\hline 24 & $\mathrm{C}$ & -0.3145 & -0.31645 & 24 & $\mathrm{C}$ & -0.31418 & -0.31685 \\
\hline 25 & $\mathrm{C}$ & -0.32162 & -0.32217 & 25 & $\mathrm{C}$ & -0.31836 & -0.31921 \\
\hline 26 & $\mathrm{C}$ & 0.05309 & 0.05169 & 26 & $\mathrm{C}$ & 0.03722 & 0.03911 \\
\hline 27 & $\mathrm{C}$ & -0.31074 & -0.31217 & 27 & $\mathrm{C}$ & -0.31306 & -0.31459 \\
\hline 28 & $\mathrm{C}$ & -0.33367 & -0.33536 & 28 & $\mathrm{C}$ & -0.33572 & -0.33768 \\
\hline 29 & $\mathrm{C}$ & 0.15887 & 0.16828 & 29 & $\mathrm{C}$ & 0.16241 & 0.16996 \\
\hline 30 & $\mathrm{C}$ & -0.36417 & -0.36923 & 30 & $\mathrm{C}$ & -0.36498 & -0.36949 \\
\hline 31 & $\mathrm{C}$ & -0.2996 & -0.29698 & 31 & $\mathrm{C}$ & -0.29878 & -0.29611 \\
\hline 32 & $\mathrm{O}$ & -0.54748 & -0.54509 & 32 & $\mathrm{O}$ & -0.54583 & -0.55022 \\
\hline 33 & $\mathrm{H}$ & 0.1048 & 0.10177 & 33 & $\mathrm{H}$ & 0.12979 & 0.12677 \\
\hline 34 & $\mathrm{H}$ & 0.09295 & 0.09169 & 34 & $\mathrm{H}$ & 0.09161 & 0.09019 \\
\hline 35 & $\mathrm{H}$ & 0.08495 & 0.08254 & 35 & $\mathrm{H}$ & 0.09965 & 0.09586 \\
\hline 36 & $\mathrm{H}$ & 0.05337 & 0.05213 & 36 & $\mathrm{H}$ & 0.13211 & 0.13113 \\
\hline 37 & $\mathrm{H}$ & 0.10024 & 0.09727 & 37 & $\mathrm{H}$ & 0.08427 & 0.0821 \\
\hline 38 & $\mathrm{H}$ & 0.0719 & 0.07075 & 38 & $\mathrm{H}$ & 0.13803 & 0.13532 \\
\hline 39 & $\mathrm{H}$ & 0.0885 & 0.0889 & 39 & $\mathrm{H}$ & 0.07823 & 0.07888 \\
\hline 40 & $\mathrm{H}$ & 0.09337 & 0.09139 & 40 & $\mathrm{H}$ & 0.08748 & 0.08604 \\
\hline 41 & $\mathrm{H}$ & 0.08774 & 0.08523 & 41 & $\mathrm{H}$ & 0.07866 & 0.07653 \\
\hline 42 & $\mathrm{H}$ & 0.08704 & 0.08641 & 42 & $\mathrm{H}$ & 0.09884 & 0.09788 \\
\hline 43 & $\mathrm{H}$ & 0.06821 & 0.06817 & 43 & $\mathrm{H}$ & 0.10117 & 0.09971 \\
\hline 44 & $\mathrm{H}$ & 0.08341 & 0.08274 & 44 & $\mathrm{H}$ & 0.07921 & 0.0789 \\
\hline 45 & $\mathrm{H}$ & 0.09383 & 0.0913 & 45 & $\mathrm{H}$ & 0.0897 & 0.08761 \\
\hline 46 & $\mathrm{H}$ & 0.08689 & 0.08867 & 46 & $\mathrm{H}$ & 0.09033 & 0.09176 \\
\hline 47 & $\mathrm{H}$ & 0.08982 & 0.08987 & 47 & $\mathrm{H}$ & 0.08277 & 0.08326 \\
\hline 48 & $\mathrm{H}$ & 0.08967 & 0.08751 & 48 & $\mathrm{H}$ & 0.09089 & 0.08839 \\
\hline 49 & $\mathrm{H}$ & 0.09365 & 0.09198 & 49 & $\mathrm{H}$ & 0.08868 & 0.08699 \\
\hline 50 & $\mathrm{H}$ & 0.08919 & 0.08727 & 50 & $\mathrm{H}$ & 0.09186 & 0.0901 \\
\hline 51 & $\mathrm{H}$ & 0.09946 & 0.09543 & 51 & $\mathrm{H}$ & 0.1076 & 0.10509 \\
\hline 52 & $\mathrm{H}$ & 0.08699 & 0.08781 & 52 & $\mathrm{H}$ & 0.08374 & 0.08357 \\
\hline 53 & $\mathrm{H}$ & 0.08231 & 0.0818 & 53 & $\mathrm{H}$ & 0.08349 & 0.08281 \\
\hline 54 & $\mathrm{H}$ & 0.06581 & 0.06409 & 54 & $\mathrm{H}$ & 0.12012 & 0.11787 \\
\hline 55 & $\mathrm{H}$ & 0.09886 & 0.09787 & 55 & $\mathrm{H}$ & 0.09005 & 0.08945 \\
\hline
\end{tabular}


Table 3. Cont.

\begin{tabular}{|c|c|c|c|c|c|c|c|}
\hline \multicolumn{4}{|c|}{ BE } & \multicolumn{4}{|c|}{ BES } \\
\hline Label & Symbol & CAM-B3LYP & B3LYP & Label & Symbol & CAM-B3LYP & B3LYP \\
\hline 56 & $\mathrm{H}$ & 0.1011 & 0.10052 & 56 & $\mathrm{H}$ & 0.11287 & 0.11204 \\
\hline 57 & $\mathrm{H}$ & 0.09352 & 0.09118 & 57 & $\mathrm{H}$ & 0.08921 & 0.08717 \\
\hline 58 & $\mathrm{H}$ & 0.08797 & 0.08677 & 58 & $\mathrm{H}$ & 0.08784 & 0.08778 \\
\hline 59 & $\mathrm{H}$ & 0.30411 & 0.30184 & 59 & $\mathrm{H}$ & 0.1285 & 0.12782 \\
\hline 60 & $\mathrm{H}$ & 0.10399 & 0.10187 & 60 & $\mathrm{H}$ & 0.09061 & 0.08926 \\
\hline 61 & $\mathrm{H}$ & 0.09188 & 0.09124 & 61 & $\mathrm{H}$ & 0.09559 & 0.09434 \\
\hline 62 & $\mathrm{H}$ & 0.09807 & 0.09677 & 62 & $\mathrm{H}$ & 0.0856 & 0.08599 \\
\hline 63 & $\mathrm{H}$ & 0.0944 & 0.09438 & 63 & $\mathrm{H}$ & 0.09401 & 0.09461 \\
\hline 64 & $\mathrm{H}$ & 0.09969 & 0.09982 & 64 & $\mathrm{H}$ & 0.09462 & 0.09426 \\
\hline 65 & $\mathrm{H}$ & 0.09838 & 0.09805 & 65 & $\mathrm{H}$ & 0.0911 & 0.09123 \\
\hline 66 & $\mathrm{H}$ & 0.09449 & 0.0942 & 66 & $\mathrm{H}$ & 0.09448 & 0.09386 \\
\hline 67 & $\mathrm{H}$ & 0.10248 & 0.10202 & 67 & $\mathrm{H}$ & 0.09695 & 0.09611 \\
\hline 68 & $\mathrm{H}$ & 0.09944 & 0.09872 & 68 & $\mathrm{H}$ & 0.1333 & 0.13009 \\
\hline 69 & $\mathrm{H}$ & 0.0819 & 0.08019 & 69 & $\mathrm{H}$ & 0.11729 & 0.11281 \\
\hline 70 & $\mathrm{H}$ & 0.1016 & 0.10022 & 70 & $\mathrm{H}$ & 0.10554 & 0.10448 \\
\hline 71 & $\mathrm{H}$ & 0.10214 & 0.10139 & 71 & $\mathrm{H}$ & 0.09637 & 0.09664 \\
\hline 72 & $\mathrm{H}$ & 0.09582 & 0.0964 & 72 & $\mathrm{H}$ & 0.09323 & 0.09188 \\
\hline 73 & $\mathrm{H}$ & 0.09797 & 0.09658 & 73 & $\mathrm{H}$ & 0.10952 & 0.1082 \\
\hline 74 & $\mathrm{H}$ & 0.09717 & 0.09619 & 74 & $\mathrm{H}$ & 0.09666 & 0.09747 \\
\hline 75 & $\mathrm{H}$ & 0.09912 & 0.09985 & 75 & $\mathrm{H}$ & 0.10339 & 0.10164 \\
\hline 76 & $\mathrm{H}$ & 0.10177 & 0.1 & 76 & $\mathrm{H}$ & 0.11443 & 0.11385 \\
\hline 77 & $\mathrm{H}$ & 0.11392 & 0.11365 & 77 & $\mathrm{H}$ & 0.10407 & 0.1031 \\
\hline 78 & $\mathrm{H}$ & 0.10872 & 0.10765 & 78 & $\mathrm{H}$ & 0.11323 & 0.1131 \\
\hline 79 & $\mathrm{H}$ & 0.11357 & 0.11327 & 79 & $\mathrm{H}$ & 0.09275 & 0.09116 \\
\hline 80 & $\mathrm{H}$ & 0.09079 & 0.08897 & 80 & $\mathrm{H}$ & 0.08375 & 0.0818 \\
\hline 81 & $\mathrm{H}$ & 0.08773 & 0.08596 & 81 & $S$ & 1.40967 & 1.41359 \\
\hline 82 & $\mathrm{H}$ & 0.30721 & 0.30457 & 82 & $\mathrm{O}$ & -0.62093 & -0.6217 \\
\hline - & - & - & - & 83 & $\mathrm{O}$ & -0.52194 & -0.52206 \\
\hline - & - & - & - & 84 & $\mathrm{O}$ & -0.64718 & -0.64532 \\
\hline- & - & - & - & 85 & $\mathrm{Na}$ & 0.59859 & 0.60197 \\
\hline- & - & - & - & 86 & $S$ & 1.44977 & 1.45217 \\
\hline - & - & - & - & 87 & $\mathrm{O}$ & -0.53987 & -0.53873 \\
\hline - & - & - & - & 88 & $\mathrm{O}$ & -0.62287 & -0.62426 \\
\hline - & - & - & - & 89 & $\mathrm{O}$ & -0.65891 & -0.65632 \\
\hline - & - & - & - & 90 & $\mathrm{Na}$ & 0.60311 & 0.60553 \\
\hline
\end{tabular}

It should be noted that the introduction of a sulfate group into the betulin molecule affects almost all Mulliken atomic charges of all atoms in the system. Therefore, in the CAMB3LYP and B3LYP calculations, the Mulliken atomic charges for C2 and C26 decrease from 0.18481 to 0.18324 e and increase from 0.18906 to 0.18934 , respectively, as was confirmed in $[40,41]$, which, in turn, is related to the electrophilic-nucleophilic effects [81-83].

\subsubsection{Spectroscopic Analysis}

The physicochemical characteristics of natural compounds can be successfully determined by the DFT method [84-87]. An important aspect of the theoretical spectroscopic studies is obtaining FTIR and NMR spectroscopy data [88-93].

To carry out thorough spectroscopic investigations of the initial and sulfated betulin, we calculated theoretical FTIR and NMR spectra. The theoretical FTIR spectra of the initial and sulfated betulin contain several absorption bands with different relative intensities. The spectra were calculated for the DFT method with the $6-31+G(d, p)$ basis set (Figure 9, Table 4). 


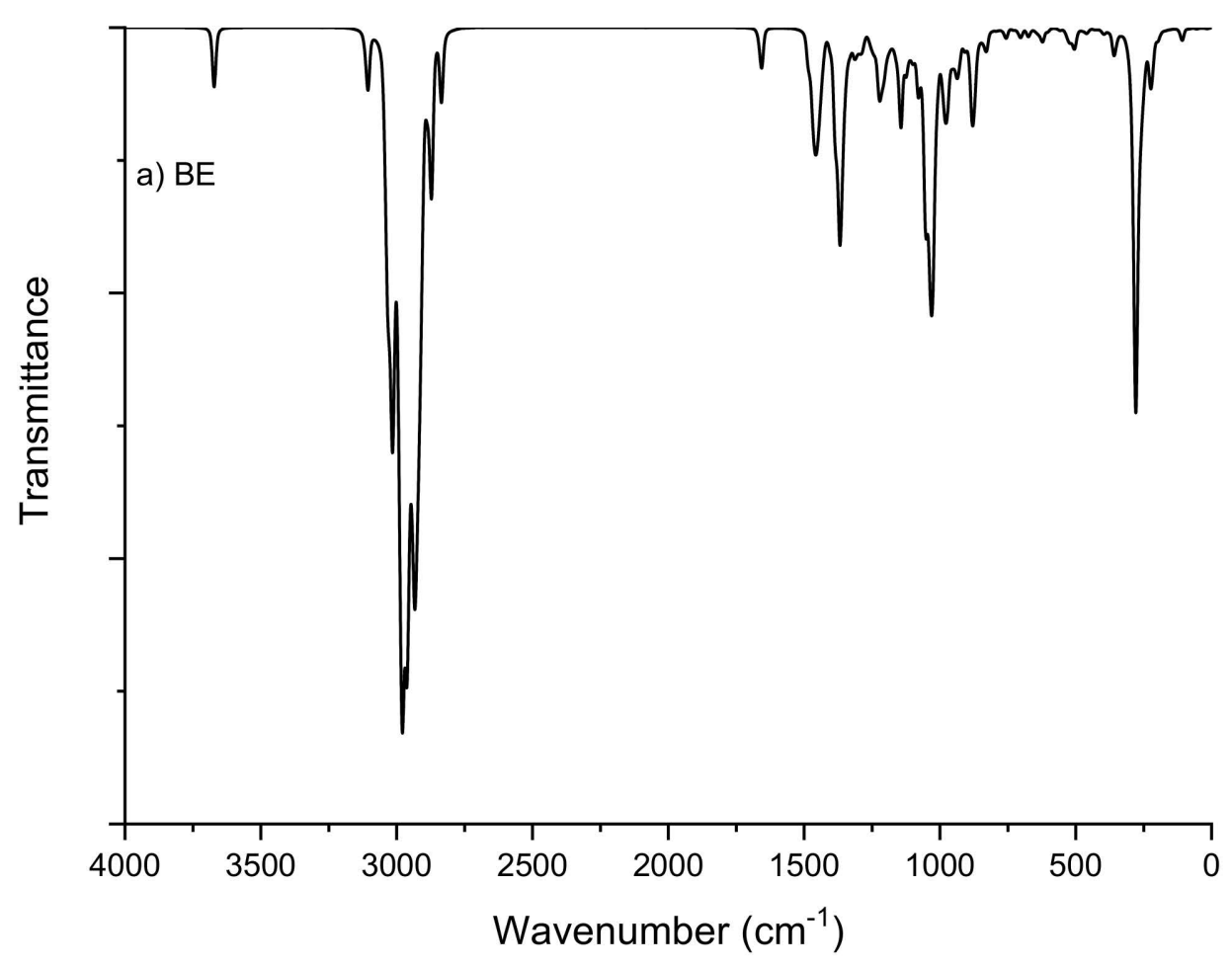

(a)

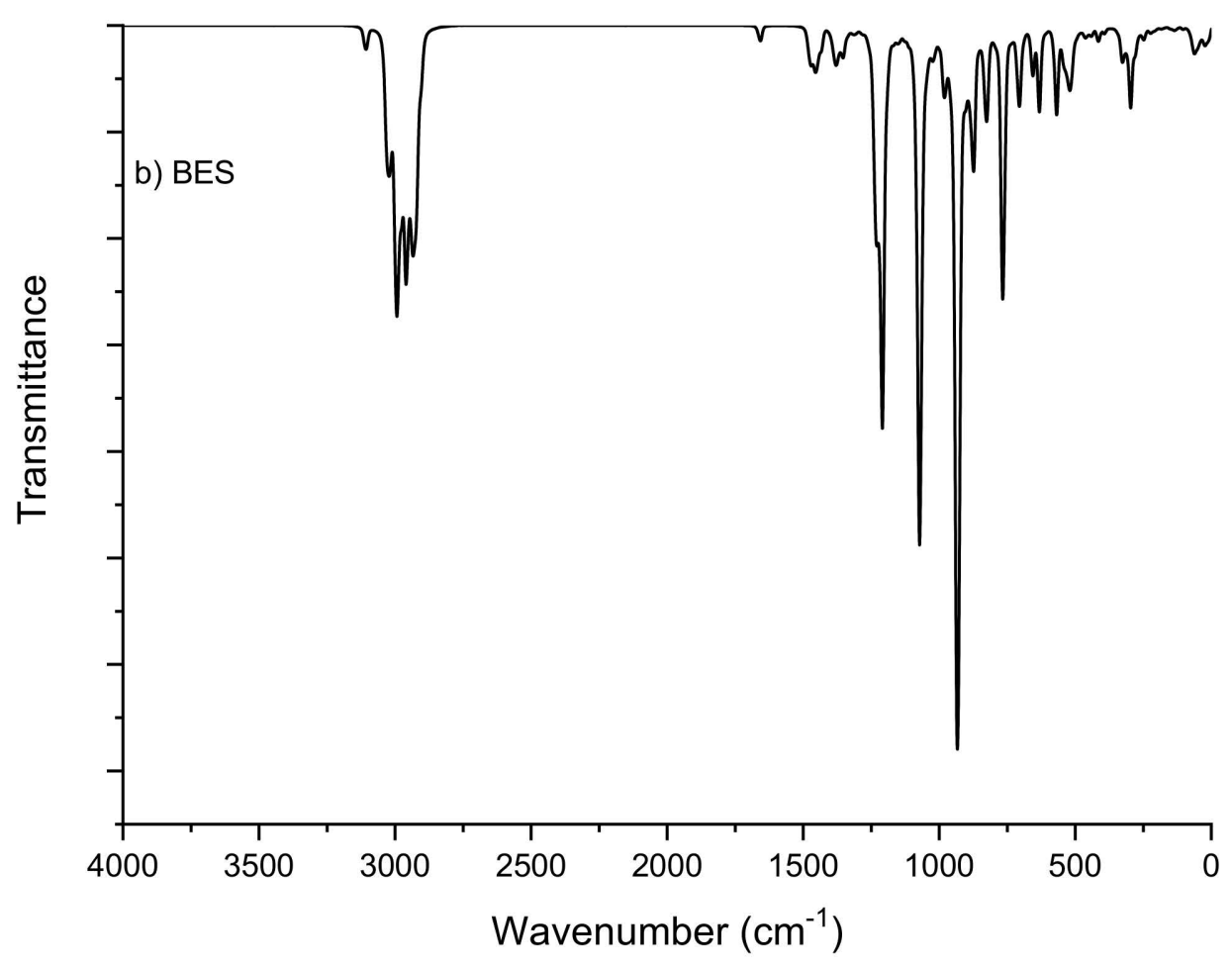

(b)

Figure 9. Theoretical FTIR spectra at B3LYP $/ 6-31+\mathrm{G}\left(\mathrm{d}\right.$, p) scaled by $0.9608 \mathrm{~cm}^{-1}$ for (a) betulin and (b) betulin sulfate. 
Table 4. Some important FTIR data $\left(\mathrm{cm}^{-1}\right)$ calculated at B3LYP/6-31 + G (d, p) for betulin (BE) and betulin sulfate (BES) and scaled by a factor of 0.9608 .

\begin{tabular}{cccc}
\hline & BE & \multicolumn{2}{c}{ BES } \\
\hline $\mathrm{O}-\mathrm{H}$ & 3671 and 3670 & $\mathrm{C}-\mathrm{H}\left(\mathrm{CH}_{2}=\right)$ & 3107 and 3032 \\
\hline $\mathrm{C}-\mathrm{H}\left(\mathrm{CH}_{2}=\right)$ & 3107 and 3032 & $\mathrm{C}-\mathrm{H}$ & $3033-2901$ \\
$\mathrm{C}-\mathrm{H}$ & $3038-2835$ & $\mathrm{C}-\mathrm{H}\left(=\mathrm{C}-\mathrm{CH}_{3}\right)$ & 2998 and 2905 \\
$\mathrm{C}-\mathrm{H}(=\mathrm{C}-\mathrm{CH} 3)$ & 3002 and 2906 & $\mathrm{C}=\mathrm{C}$ & 1658 \\
$\mathrm{C}-\mathrm{H}(\mathrm{CH} 2-\mathrm{OH})$ & 2954 and 2870 & $\mathrm{O}-\mathrm{S}$ & $1227,1209,1074,1068$, \\
$\mathrm{CH}(\mathrm{CH}-\mathrm{OH})$ & 2940 and 2925 & $\mathrm{CH}(\mathrm{O}-)$ & 941,931 \\
$\mathrm{C}=\mathrm{C}$ & 1657 & $\mathrm{Na}-\mathrm{O}$ & $2984,1474,1210$ \\
\hline
\end{tabular}

\subsubsection{O-H Vibration}

It is well-known $[94,95]$ that vibrations of the $\mathrm{O}-\mathrm{H}$ group are most sensitive to the environment. The presence of a hydrogen bond in such a compound allows one to shift to the low-frequency regions with an increase in the intensity in the FTIR spectra. In the theoretical FTIR spectra of the initial betulin, stretching vibrations of $\mathrm{OH}$ groups were observed around 3671 and $3670 \mathrm{~cm}^{-1}$. In sulfated betulin, these fluctuations were not observed due to the complete replacement of the hydroxyl group by the sulfate group.

\subsubsection{C-H Vibration}

The heterocyclic $\mathrm{CH}$ group gives rise to several fundamental frequencies, including stretching (symmetric and asymmetric in-plane and out-of-plane bending vibrations). The stretching modes (asymmetric and symmetric) usually appear at 3100 and $3000 \mathrm{~cm}^{-1}[96,97]$. In the theoretical FTIR spectra, vibrations of the $\mathrm{C}-\mathrm{H}$ group in the betulin samples were observed at 3107,3032 , and $3038-2835 \mathrm{~cm}^{-1}$. For betulin sulfate, vibrations of $\mathrm{C}-\mathrm{H}$ groups are observed at 3107 and 3032, 3033-2901, and $2984 \mathrm{~cm}^{-1}$.

\subsection{7. $\mathrm{C}=\mathrm{C}$ Vibration}

In the theoretical FTIR spectra, stretching vibrations of the $\mathrm{C}=\mathrm{C}$ group for betulin and betulin sulfate were observed at 1657 and $1658 \mathrm{~cm}^{-1}$, respectively.

\subsubsection{O-S Vibration}

In the theoretical FTIR spectra, stretching vibrations of the O-S group for sulfated betulin was observed at 1227, 1209, 1074, 1068, 941, and $931 \mathrm{~cm}^{-1}$. In the experimental FTIR spectra, vibrations of this group were observed around $1249 \mathrm{~cm}^{-1}$ and $835-841 \mathrm{~cm}^{-1}$, which is consistent with the results reported in $[56,98]$.

In addition, to estimate the qualitative changes in betulin during sulfation, theoretical NMR spectra were calculated (Figure 10, Table 5). According to the data given in Table 5, a strong signal shift from 67.3998 to $80.5108 \mathrm{ppm}$ for the C3 atom (C2 in the table) and from 61.5732 to $63.9693 \mathrm{ppm}$ for the $\mathrm{C} 28$ atom (C26 in the table) is observed. The results obtained agree well with the experimental data presented in Figure 11. The difference in numbering is explained by the different numbering in the classical nomenclature of the chemistry of tripertinoid compounds and in software.

Table 5. ${ }^{1} \mathrm{HNMR}$ and ${ }^{13} \mathrm{CNMR}$ data for betulin (BE) and sulfated betulin (BES) calculated at B3LYP/6-31 + G (d, p).

\begin{tabular}{cccccccc}
\hline & \multicolumn{2}{c}{ BE } & \multicolumn{3}{c}{ BES } \\
\hline $\begin{array}{c}\text { Hydrogen } \\
\text { Atom }\end{array}$ & $\begin{array}{c}\text { Chemical } \\
\text { Shift }(\mathbf{p p m})\end{array}$ & $\begin{array}{c}\text { Carbon } \\
\text { Atom }\end{array}$ & $\begin{array}{c}\text { Chemical } \\
\text { Shift (ppm) }\end{array}$ & $\begin{array}{c}\text { Hydrogen } \\
\text { Atom }\end{array}$ & $\begin{array}{c}\text { Chemical } \\
\text { Shift (ppm) }\end{array}$ & $\begin{array}{c}\text { Carbon } \\
\text { Atom }\end{array}$ & $\begin{array}{c}\text { Chemical } \\
\text { Shift (ppm) }\end{array}$ \\
\hline $80-\mathrm{H}$ & 5.1189 & $29-\mathrm{C}$ & 140.0163 & $79-\mathrm{H}$ & 5.156 & $29-\mathrm{C}$ & 140.1273 \\
$81-\mathrm{H}$ & 5.0522 & $31-\mathrm{C}$ & 93.0736 & $80-\mathrm{H}$ & 5.0961 & $31-\mathrm{C}$ & 93.0158 \\
$69-\mathrm{H}$ & 3.8844 & $2-\mathrm{C}$ & 67.3998 & $68-\mathrm{H}$ & 4.2101 & $2-\mathrm{C}$ & 80.5108 \\
\hline
\end{tabular}


Table 5. Cont.

\begin{tabular}{|c|c|c|c|c|c|c|c|}
\hline \multicolumn{4}{|c|}{$\mathrm{BE}$} & \multicolumn{4}{|c|}{ BES } \\
\hline $\begin{array}{l}\text { Hydrogen } \\
\text { Atom }\end{array}$ & $\begin{array}{l}\text { Chemical } \\
\text { Shift (ppm) }\end{array}$ & $\begin{array}{c}\text { Carbon } \\
\text { Atom }\end{array}$ & $\begin{array}{l}\text { Chemical } \\
\text { Shift (ppm) }\end{array}$ & $\begin{array}{l}\text { Hydrogen } \\
\text { Atom }\end{array}$ & $\begin{array}{l}\text { Chemical } \\
\text { Shift (ppm) }\end{array}$ & $\begin{array}{l}\text { Carbon } \\
\text { Atom }\end{array}$ & $\begin{array}{c}\text { Chemical } \\
\text { Shift (ppm) }\end{array}$ \\
\hline $35-\mathrm{H}$ & 3.4006 & $26-C$ & 61.5732 & $35-\mathrm{H}$ & 4.1063 & $26-C$ & 63.9693 \\
\hline 70-H & 3.2142 & $10-C$ & 44.2637 & $69-\mathrm{H}$ & 3.644 & $10-C$ & 42.9424 \\
\hline $58-\mathrm{H}$ & 3.0378 & $4-C$ & 42.8496 & $58-\mathrm{H}$ & 3.1113 & $18-\mathrm{C}$ & 41.8903 \\
\hline $44-\mathrm{H}$ & 2.2612 & $18-\mathrm{C}$ & 41.2406 & $36-\mathrm{H}$ & 2.7828 & $21-C$ & 40.439 \\
\hline 34-H & 2.2327 & $17-C$ & 40.3549 & $33-\mathrm{H}$ & 2.6308 & $4-C$ & 40.0096 \\
\hline $57-\mathrm{H}$ & 2.2152 & $21-C$ & 40.2103 & 57-H & 2.311 & $17-C$ & 38.9887 \\
\hline 79-H & 2.0347 & $9-C$ & 38.2528 & $44-\mathrm{H}$ & 2.2933 & $9-C$ & 38.1393 \\
\hline $55-\mathrm{H}$ & 2.0335 & $11-\mathrm{C}$ & 36.727 & $34-\mathrm{H}$ & 2.124 & $11-\mathrm{C}$ & 36.4112 \\
\hline $77-\mathrm{H}$ & 1.9339 & $3-C$ & 32.7851 & $38-\mathrm{H}$ & 2.1138 & $3-C$ & 32.9181 \\
\hline 49-H & 1.9317 & $5-C$ & 32.6781 & 78-H & 2.0739 & $5-C$ & 32.3275 \\
\hline $51-\mathrm{H}$ & 1.8729 & $12-\mathrm{C}$ & 29.4602 & $55-\mathrm{H}$ & 2.0641 & $12-\mathrm{C}$ & 29.5149 \\
\hline 39-H & 1.8035 & $20-C$ & 26.4429 & 76-H & 1.9848 & $20-C$ & 26.7763 \\
\hline $53-\mathrm{H}$ & 1.796 & $6-C$ & 25.4542 & 54-H & 1.9815 & $6-C$ & 25.9807 \\
\hline 78-H & 1.7151 & $8-C$ & 24.085 & $49-\mathrm{H}$ & 1.9654 & $8-C$ & 23.9728 \\
\hline 47-H & 1.6804 & $16-C$ & 22.1573 & $53-\mathrm{H}$ & 1.9604 & $19-C$ & 22.9769 \\
\hline $43-\mathrm{H}$ & 1.6769 & $19-C$ & 22.0667 & $43-\mathrm{H}$ & 1.944 & $16-\mathrm{C}$ & 21.3784 \\
\hline $42-\mathrm{H}$ & 1.6543 & $15-C$ & 20.998 & 51-H & 1.844 & $15-C$ & 20.8974 \\
\hline 48-H & 1.6326 & $23-C$ & 20.0705 & 39-H & 1.7884 & $23-C$ & 18.9603 \\
\hline $37-\mathrm{H}$ & 1.6259 & $13-\mathrm{C}$ & 18.8465 & 77-H & 1.7473 & $13-\mathrm{C}$ & 18.6958 \\
\hline $46-\mathrm{H}$ & 1.6253 & $1-C$ & 17.938 & $42-\mathrm{H}$ & 1.7136 & $30-C$ & 16.8118 \\
\hline $40-\mathrm{H}$ & 1.582 & $30-C$ & 16.8562 & $47-\mathrm{H}$ & 1.6841 & $1-C$ & 14.6996 \\
\hline $33-\mathrm{H}$ & 1.563 & $14-\mathrm{C}$ & 14.6112 & $46-\mathrm{H}$ & 1.6692 & $27-C$ & 14.5464 \\
\hline $41-\mathrm{H}$ & 1.5611 & $27-C$ & 13.6592 & 48-H & 1.654 & $14-\mathrm{C}$ & 14.3916 \\
\hline 74-H & 1.5597 & $28-C$ & 13.0177 & $40-\mathrm{H}$ & 1.6504 & $28-C$ & 12.8152 \\
\hline 54-H & 1.5306 & $7-C$ & 12.1492 & 73-H & 1.6266 & $7-C$ & 12.3059 \\
\hline $45-\mathrm{H}$ & 1.5145 & $25-C$ & 7.8876 & $45-\mathrm{H}$ & 1.5462 & $24-C$ & 7.7267 \\
\hline 68-H & 1.494 & $24-C$ & 7.6367 & $41-\mathrm{H}$ & 1.5179 & $25-C$ & 7.5684 \\
\hline $52-\mathrm{H}$ & 1.4371 & - & - & $52-\mathrm{H}$ & 1.5156 & - & - \\
\hline $56-\mathrm{H}$ & 1.3537 & - & - & $37-\mathrm{H}$ & 1.4956 & - & - \\
\hline 59-H & 1.3506 & - & - & $56-\mathrm{H}$ & 1.4865 & - & - \\
\hline $50-\mathrm{H}$ & 1.2945 & - & - & $67-\mathrm{H}$ & 1.4568 & - & - \\
\hline 76-H & 1.2901 & - & - & 75-H & 1.3469 & - & - \\
\hline $72-\mathrm{H}$ & 1.2891 & - & - & 59-H & 1.3319 & - & - \\
\hline $36-\mathrm{H}$ & 1.2623 & - & - & $50-\mathrm{H}$ & 1.3168 & - & - \\
\hline $60-\mathrm{H}$ & 1.2384 & - & - & $60-\mathrm{H}$ & 1.2996 & - & - \\
\hline 61-H & 1.196 & - & - & 71-H & 1.2321 & - & - \\
\hline 38-H & 1.1732 & - & - & $70-\mathrm{H}$ & 1.1811 & - & - \\
\hline 71-H & 1.1562 & - & - & $63-\mathrm{H}$ & 1.1485 & - & - \\
\hline 64-H & 1.1243 & - & - & $65-\mathrm{H}$ & 1.1308 & - & - \\
\hline $75-\mathrm{H}$ & 1.1019 & - & - & $74-\mathrm{H}$ & 1.1244 & - & - \\
\hline 66-H & 1.0916 & - & - & $64-\mathrm{H}$ & 0.965 & - & - \\
\hline 63-H & 1.0154 & - & - & $62-\mathrm{H}$ & 0.9579 & - & - \\
\hline 65-H & 0.9691 & - & - & 61-H & 0.9354 & - & - \\
\hline $67-\mathrm{H}$ & 0.8833 & - & - & $66-\mathrm{H}$ & 0.8736 & - & - \\
\hline 82-H & 0.8301 & - & - & 72-H & 0.5335 & - & - \\
\hline $62-\mathrm{H}$ & 0.7253 & - & - & - & - & - & - \\
\hline 73-H & 0.6054 & - & - & - & - & - & - \\
\hline
\end{tabular}




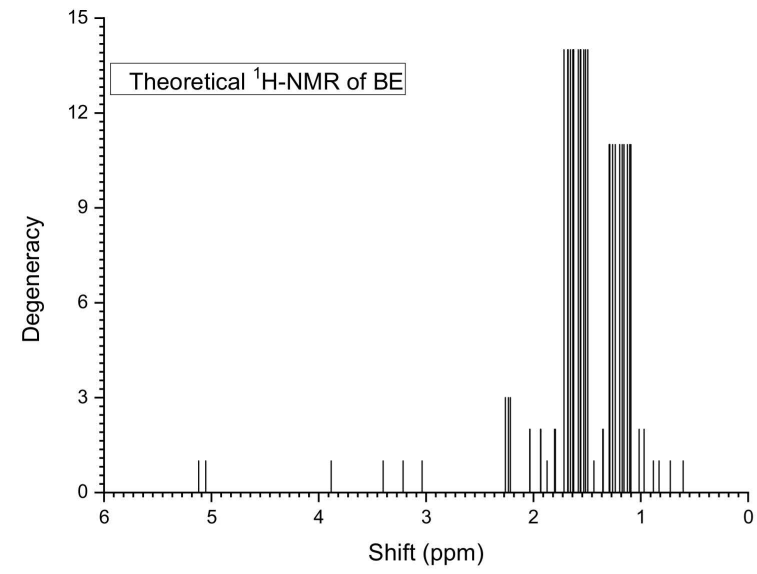

(a)

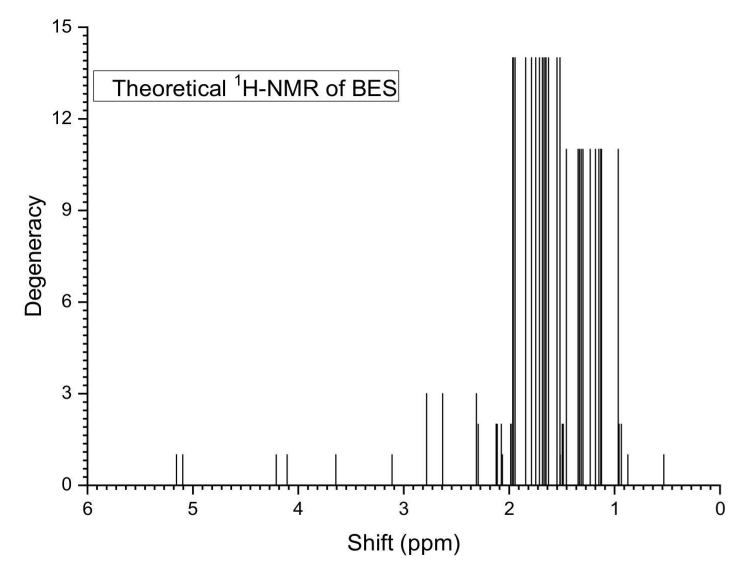

(c)

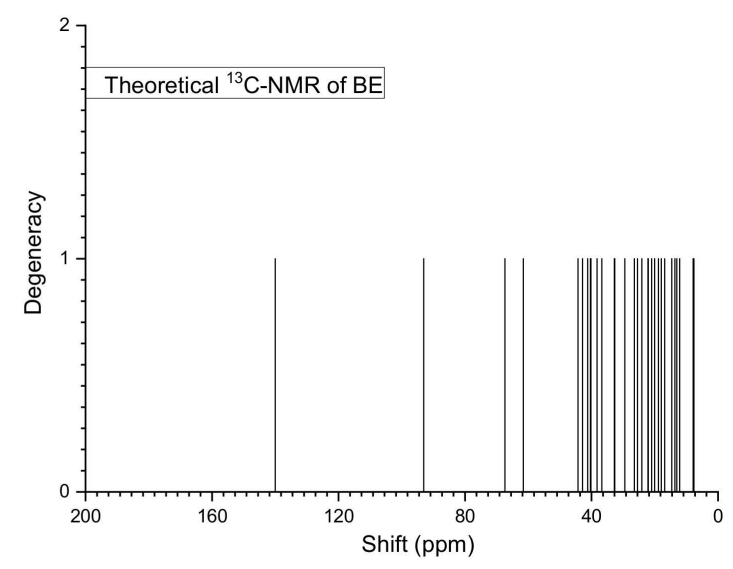

(b)

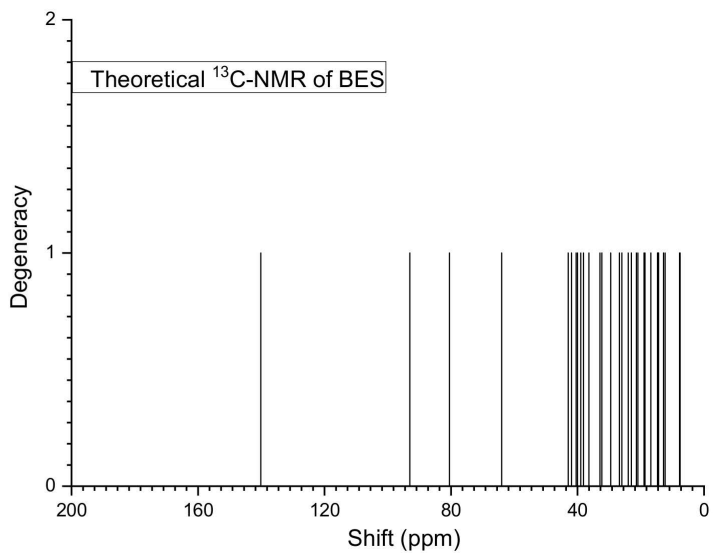

(d)

Figure 10. Theoretical ${ }^{1} \mathrm{H}$ and ${ }^{13} \mathrm{C}$ NMR spectra of betulin (BE) and sulfated betulin (BES) at B3LYP / 6-31 + G (d, p).

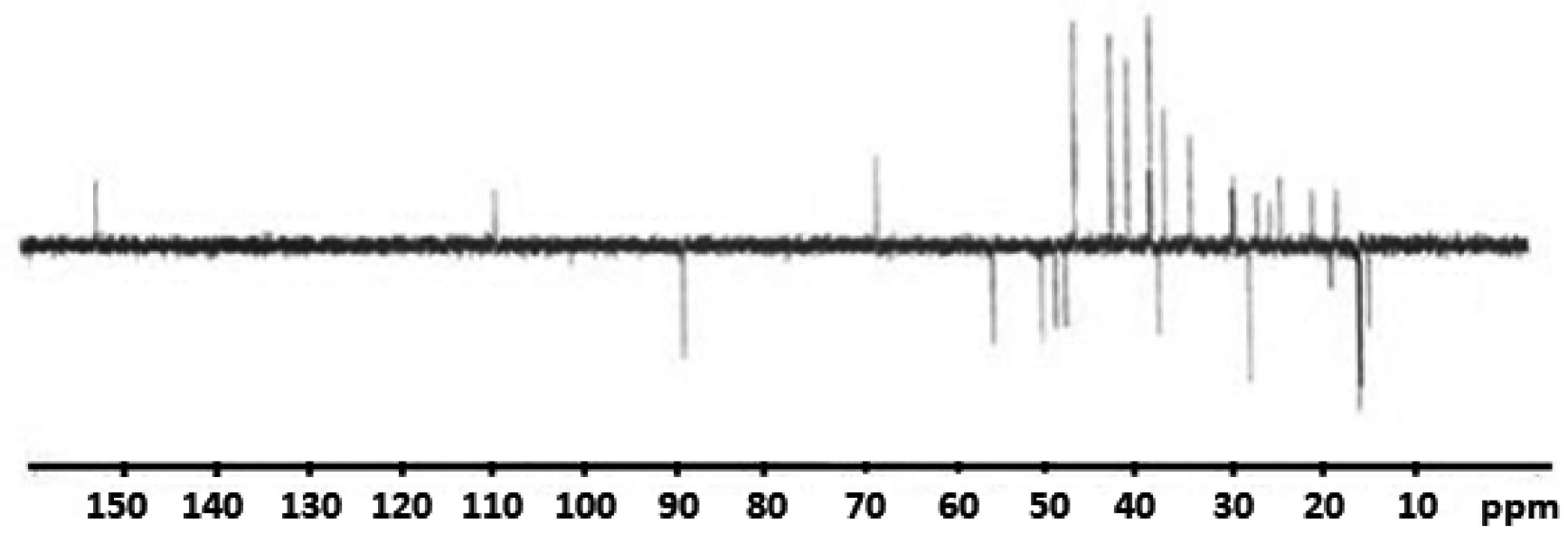

Figure 11. NMR spectrum of the betulin disulfate sodium salt. 


\section{Material and Methods}

\subsection{Sulfation of Betulin}

In the sulfation experiment, $50 \mathrm{~mL}$ of dehydrated pyridine, $6 \mathrm{~g}$ of sulfamic acid, and $2 \mathrm{~g}$ of betulin were placed in a $100 \mathrm{~mL}$ three-necked flask equipped with a mechanical stirrer and a thermostat. The reaction mass was heated to $90{ }^{\circ} \mathrm{C}, 0.3 \mathrm{~g}$ of an Amberlyst ${ }^{\circledR} 15$ catalyst was added, and the mixture was kept at this temperature for $0.5-2.5 \mathrm{~h}$. Then, the reaction mixture was cooled down to $10-15^{\circ} \mathrm{C}$, diluted with $30 \mathrm{~mL}$ of water, and neutralized with the $10 \%$ aqueous sodium hydroxide solution to $\mathrm{pH}$; the catalyst solution was separated by filtration on a paper filter. The solution was evaporated to dryness under a water jet vacuum pump. The solid residue was added with anhydrous ethanol $(70 \mathrm{~mL})$ and the mixture was refluxed for $30 \mathrm{~min}$. The hot mixture was filtered and the mother liquor was evaporated to dryness under a water jet vacuum pump. In the physicochemical investigations, betulin disulfate recrystallized from ethanol with the maximum sulfur content was used.

The betulin disulfate $\mathrm{H}$-form was obtained from the betulin disulfate sodium salt by the ionic method on a KU-2-8 cation exchanger according with the procedures described in $[56,99,100]$. Previously, a commercial KU-2-8 ion exchange resin in the $\mathrm{Na}^{+}$form was transferred to the $\mathrm{H}^{+}$form. To do this, an aqueous $2 \mathrm{M} \mathrm{HCl}$ solution was transmitted through a layer of KU-2-8 resin in the $\mathrm{Na}+$ form homogeneously mixed with distilled water and placed in a $50 \mathrm{~mL}$ vertical glass column $15-20 \mathrm{~mm}$ in diameter with a tap at the bottom. The hydrochloric acid solution flew out of the column. Then, the resin was washed with distilled water until the wash water was neutral in methyl red. The solution of $\sim 1.0 \mathrm{~g}$ of betulin disulfate sodium salt recrystallized from ethanol in $50 \mathrm{~mL}$ of distilled water was transmitted through the prepared cation resin layer. After the passage of the solution of betulin disulfate sodium salt through the column, the resin in the column was washed three times with distilled water $(20 \mathrm{~mL}$ each). The washing liquids were collected and the solution was evaporated to dryness under a water jet vacuum pump at a distillation temperature of no higher than $40^{\circ} \mathrm{C}$.

The content of hydrogen ions in the $\mathrm{H}+$ form was determined by an acid-base titration. A sample weight of the $\mathrm{H}^{+}$form $(0.0400-0.0500 \mathrm{~g})$ was dissolved in $25 \mathrm{~mL}$ of water. The $5 \mathrm{~mL}$ samples were taken and the titration with $0.01 \mathrm{~N}$ sodium hydroxide solution in methyl red until the yellow solution was performed.

The acidity constant of the solution of the betulin disulfate $\mathrm{H}^{+}$form was determined by a potentiometric titration. A sample weight of the $\mathrm{H}^{+}$form $(0.0400-0.0500 \mathrm{~g})$ was dissolved in a water-alcohol solution consisting of $10 \mathrm{~mL}$ of water and $15 \mathrm{~mL}$ of ethanol. Three $20 \mathrm{~mL}$ aliquots were taken and the potentiometric titration of each of them with the $0.01 \mathrm{~N}$ sodium hydroxide solution was performed. The dependence of the solution $\mathrm{pH}$ on the titrant volume was plotted. The average value of the acidity constant was calculated using the formula

$$
\mathrm{K}=\frac{0.5 \times \mathrm{A}^{3}}{\mathrm{~B}-\frac{\mathrm{A}}{2}}
$$

where $\mathrm{A}$ is the concentration of hydrogen ions at the equivalent point $(\mathrm{mol} / \mathrm{L})$ and $\mathrm{B}$ is the initial solution concentration $(\mathrm{mol} / \mathrm{L})$.

\subsection{Methods for Physicochemical Analysis}

The elemental analysis of the sulfated samples was carried out on a Thermo Quest Flash EA-1112 elemental analyzer (Italy).

The FTIR spectra of the initial and sulfated betulin were recorded on a Shimadzu IR Tracer-100 spectrometer (Japan) in the wavelength range of $400-4000 \mathrm{~cm}^{-1}$. The spectral data were analyzed with the OPUS program (version 5.0). Solid samples for the analysis were prepared in the form of tablets in a KBr matrix (2-mg sample/1000-mg KBr).

The UV-Vis spectra were recorded on a Leki Instruments SS2109-UV scanning spectrophotometer (Finland) using 1-cm quartz cells. Cell thermostating $( \pm 0.1 \mathrm{~K})$ was performed in a Haake K15 thermostat connected to a Haake DC10 controller. The absorbance 
of the process solutions was measured within $220-400 \mathrm{~nm}$. All the measurements were performed at a temperature of $298 \mathrm{~K}$.

The ${ }^{13} \mathrm{C}$ NMR spectra were recorded on a Bruker Avance III $600 \mathrm{MHz}$ spectrometer in deuteromethanol with a reference to the deuterium resonance of the solvent.

The X-ray diffraction study was carried out on a DRON-3 X-ray diffractometer (monochromatic $\mathrm{Cu} K_{\alpha}$ radiation, $\lambda=0.154 \mathrm{~nm}$ ) at a voltage of $30 \mathrm{kV}$ and a current of $25 \mathrm{~mA}$. The scanning step was $0.02 \mathrm{deg}$ and the intervals were $1 \mathrm{~s}$ per data point. The measurements were performed at the $2 \Theta$ Bragg angles ranging from 5.00 to $70.00 \Theta$.

The thermal analysis was carried out in a corundum crucible using an STA 449 F1 Jupiter instrument (NETZSCH) in the temperature range from 30 to $600{ }^{\circ} \mathrm{C}$ at a heating rate of $10{ }^{\circ} \mathrm{C} / \mathrm{min}$ in an argon flow; the shielding and purge gas flow rates were 20 and $50 \mathrm{~mL} / \mathrm{min}$, respectively. The measured data were processed using the NETZSCH Proteus Thermal Analysis 5.1.0 software package supplied with the instrument.

\subsection{Computational Details}

All DFT calculations were performed in the Gaussian 09W [101] and Gaussview 5.0 [102] molecular package programs for the ground state and gas phase. At the first stage of the DFT study, the geometry of monomers was optimized. The two DFT methods used were the Becke's three-parameter functional $[103,104]$ and the gradient-corrected correlational functional proposed by Lee, Yang, and Parr (B3LYP) and its combination with the Coulomb attenuating method (CAM-B3LYP) $[105,106]$. For the optimized geometries, the molecular electrostatic potential (MEP) and the highest occupied molecular orbital (HOMO) - the lowest unoccupied molecular orbital (LUMO) analysis of betulin and sulfated betulin was made using the CAM-B3LYP / 6-31 + G (d, p) level of theory. The FTIR and NMR theoretical analysis was made using the B3LYP/6-31 + G $(d, p)$ level of theory.

\section{Conclusions}

A method for the sulfation of betulin with sulfamic acid in pyridine in the presence of a solid catalyst Amberlyst ${ }^{\circledR} 15$ is proposed. It has been shown that this catalyst remains stable in multicycle tests during sulfation of betulin with sulfamic acid in pyridine.

The resulting betulin sulfate was studied both by physicochemical methods, including FT-IR, UV-visible and NMR spectroscopy, X-ray diffraction analysis and TGA, and by DFT. The acidity constant of the acidic form of betulin sulfate has been studied. It is shown that the introduction of a sulfate group into the betulin molecule leads to the appearance of absorption bands in the FT-IR spectra characteristic of the S-O group. X-ray diffraction showed that sulfation leads to amorphization of the original betulin. It has been shown by UV-visible spectrophotometry that the introduction of a sulfate group into the betulin molecule leads to a decrease in the intensity of the peaks in the UV spectra. In addition, the average product of the first and second dissociation constants of the acidic form of betulin sulfate was determined.

Data on the most stable conformations and molecular electrostatic potential of betulin and betulin disulfate were obtained by the DFT method. The energy gaps for the original and sulfated betulin were found. It has been shown that betulin sulfate is more reactive than the original betulin. The DFT method was used to calculate the spectral characteristics of the original and sulfated betulin, which turned out to be in good agreement with the experimental data.

The developed sulfation method has great application potential, as it opens up new possibilities for separation, catalyst recycling, and reducing the cost of reagents.

Author Contributions: Conceptualization, A.S.K. (Aleksandr S. Kazachenko), F.A. and N.Y.V.; Methodology, N.Y.V., F.A. and A.S.K. (Aleksandr S. Kazachenko); Software, N.I., F.A.; Validation, Y.N.M., N.Y.V. and A.S.K. (Aleksandr S. Kazachenko); Formal analysis, A.S.K. (Aleksandr S. Kazachenko), and. M.J.W.; Investigation, F.A., A.S.K. (Aleksandr S. Kazachenko), A.S.K. (Anna S. Kazachenko), E.V.E., A.A.K.; Resources, N.Y.V.; Data curation, Y.N.M., N.Y.V., A.V.M., O.A.-D., Y.D.B. and A.S.K. (Anna S. Kazachenko); Writing—original draft preparation, Y.N.M. and N.Y.V.; Writing- 
review and editing, Y.N.M. and N.Y.V.; Visualization, F.A., A.V.M., V.S.B. and N.I.; Supervision, N.I., F.A., A.S.K. (Aleksandr S. Kazachenko); Project administration, A.S.K. (Aleksandr S. Kazachenko). All authors have read and agreed to the published version of the manuscript.

Funding: The author would like to thank the Bingöl University for providing a server and the Bitlis Eren University for providing the Gaussian software. The experiments were supported by the budget plan no. 0287-2021-0017 for the Institute of Chemistry and Chemical Technology, Siberian Branch of the Russian Academy of Sciences and carried out on the equipment of the Krasnoyarsk Regional Center for Collective Use, Krasnoyarsk Scientific Center, Siberian Branch of the Russian Academy of Sciences. The methodology work was supported by the Researchers Supporting Project no. RSP-2021/61, King Saud University, Riyadh, Saudi Arabia.

Institutional Review Board Statement: Not applicable.

Informed Consent Statement: N/A. This work does not contain any studies involving animals or humans carried out by any of the authors.

Data Availability Statement: Data sharing not applicable to this article as no datasets were generated or analysed during the current study. All the data generated during this study are included in this article.

Conflicts of Interest: The authors declare no conflict of interest.

Sample Availability: Samples of the compounds are available from the authors.

\section{References}

1. Kazachenko, A.S.; Miroshnikova, A.V.; Tarabanko, V.E.; Skripnikov, A.M.; Malyar, Y.N.; Borovkova, V.S.; Sychev, V.V.; Taran, O.P. Thermal Conversion of Flax Shives in Sub- and Supercritical Ethanol in the Presence of Ru/C Catalyst. Catalysts 2021, 11, 970. [CrossRef]

2. Kuznetsov, B.N.; Baryshnikov, S.V.; Miroshnikova, A.V.; Kazachenko, A.S.; Malyar, Y.N.; Skripnikov, A.M.; Taran, O.P. Fractionation of Birch Wood by Integrating Alkaline-Acid Treatments and Hydrogenation in Ethanol over a Bifunctional Ruthenium Catalyst. Catalysts 2021, 11, 1362. [CrossRef]

3. Kazachenko, A.S.; Tarabanko, V.E.; Miroshnikova, A.V.; Sychev, V.V.; Skripnikov, A.M.; Malyar, Y.N.; Mikhlin, Y.L.; Baryshnikov, S.V.; Taran, O.P. Reductive Catalytic Fractionation of Flax Shive over Ru/C Catalysts. Catalysts 2021, 11, 42. [CrossRef]

4. Gallezot, P. Conversion of biomass to selected chemical products. Chem. Soc. Rev. 2012, 41, 1538-1558. [CrossRef] [PubMed]

5. Zhao, X.; Zhou, H.; Sikarwar, V.S.; Zhao, M.; Park, A.-H.A.; Fennell, P.S.; Shen, L.; Fan, L.-S. Biomass-based chemical looping technologies: The good, the bad and the future. Energy Environ. Sci. 2017, 10, 1885-1910. [CrossRef]

6. Borovkova, V.S.; Malyar, Y.N.; Sudakova, I.G.; Chudina, A.I.; Skripnikov, A.M.; Fetisova, O.Y.; Kazachenko, A.S.; Miroshnikova, A.V.; Zimonin, D.V.; Ionin, V.A.; et al. Molecular Characteristics and Antioxidant Activity of Spruce (Picea abies) Hemicelluloses Isolated by Catalytic Oxidative Delignification. Molecules 2022, 27, 266. [CrossRef]

7. Lachowicz, H.; Wróblewska, H.; Sajdak, M.; Komorowicz, M.; Wojtan, R. The chemical composition of silver birch (Betula pendula Roth.) wood in Poland depending on forest stand location and forest habitat type. Cellulose 2019, 26, 3047-3067. [CrossRef]

8. Mononen, K.; Jääskeläinen, A.-S.; Alvila, L.; Pakkanen, T.T.; Vuorinen, T. Chemical changes in silver birch (Betula pendula Roth) wood caused by hydrogen peroxide bleaching and monitored by color measurement (CIELab) and UV-Vis, FTIR and UVRR spectroscopy. Holzforschung 2005, 59, 381-388. [CrossRef]

9. Hiltunen, E.; Mononen, K.; Alvila, L.; Pakkanen, T.T. Discolouration of birch wood: Analysis of extractives from discoloured surface of vacuum-dried European white birch (Betula pubescens) board. Wood Sci. Technol. 2007, 42, 103. [CrossRef]

10. Ashour, M.; Wink, M.; Gershenzon, J. Biochemistry of Terpenoids: Monoterpenes, Sesquiterpenes and Diterpenes. In Annual Plant Reviews Volume 40: Biochemistry of Plant Secondary Metabolism; Blackwell Publishing Ltd.: Hoboken, NJ, USA, 2010 ; pp. 258-303. [CrossRef]

11. Tolstikova, T.G.; Sorokina, I.V.; Tolstikov, G.A.; Tolstikov, A.G.; Flekhter, O.B. Biological activity and pharmacological prospects of lupane terpenoids: I. natural lupane derivatives. Russ. J. Bioorg. Chem. 2006, 32, 37-49. [CrossRef]

12. Šiman, P.; Filipová, A.; Tichá, A.; Niang, M.; Bezrouk, A.; Havelek, R. Effective Method of Purification of Betulin from Birch Bark: The Importance of Its Purity for Scientific and Medicinal Use. PLoS ONE 2016, 11, e0154933. [CrossRef] [PubMed]

13. Lou, H.; Li, H.; Zhang, S.; Lu, H.; Chen, Q. A Review on Preparation of Betulinic Acid and Its Biological Activities. Molecules 2021, 26, 5583. [CrossRef]

14. Hordyjewska, A.; Ostapiuk, A.; Horecka, A.; Kurzepa, J. Betulin and betulinic acid: Triterpenoids derivatives with a powerful biological potential. Phytochem. Rev. 2019, 18, 929-951. [CrossRef]

15. Svetlana, A.K.; Tatyana, P.S.; Mikhail, A.M.; Yury, N.M.; Anna, S.K.; Valeri, A.D.; Boris, N.K. Preparation and Antitumor Activity of Betulin Dipropionate and its Composites: A minireview. Biointerface Res. Appl. Chem. 2022, 12, 6873-6894.

16. Alakurtti, S.; Mäkelä, T.; Koskimies, S.; Yli-Kauhaluoma, J. Pharmacological properties of the ubiquitous natural product betulin. Eur. J. Pharm. Sci. 2006, 29, 1-13. [CrossRef] [PubMed] 
17. Amiri, S.; Dastghaib, S.; Ahmadi, M.; Mehrbod, P.; Khadem, F.; Behrouj, H.; Aghanoori, M.-R.; Machaj, F.; Ghamsari, M.; Rosik, J.; et al. Betulin and its derivatives as novel compounds with different pharmacological effects. Biotechnol. Adv. 2020, $38,107409$. [CrossRef] [PubMed]

18. Ressmann, A.K.; Strassl, K.; Gaertner, P.; Zhao, B.; Greiner, L.; Bica, K. New aspects for biomass processing with ionic liquids: Towards the isolation of pharmaceutically active betulin. Green Chem. 2012, 14, 940-944. [CrossRef]

19. Myszka, H.; Grzywacz, D.; Zdrowowicz, M.; Spisz, P.; Butowska, K.; Rak, J.; Piosik, J.; Jaśkiewicz, M.; Kamysz, W.; Liberek, B. Design, synthesis and biological evaluation of betulin-3-yl 2-amino-2-deoxy- $\beta$-D-glycopyranosides. Bioorg. Chem. 2020, 96, 103568. [CrossRef]

20. Król, S.K.; Kiełbus, M.; Rivero-Müller, A.; Stepulak, A. Comprehensive Review on Betulin as a Potent Anticancer Agent. BioMed Res. Int. 2015, 2015, 584189. [CrossRef]

21. Heidary Navid, M.; Laszczyk-Lauer, M.N.; Reichling, J.; Schnitzler, P. Pentacyclic triterpenes in birch bark extract inhibit early step of herpes simplex virus type 1 replication. Phytomedicine 2014, 21, 1273-1280. [CrossRef]

22. Shikov, A.N.; Djachuk, G.I.; Sergeev, D.V.; Pozharitskaya, O.N.; Esaulenko, E.V.; Kosman, V.M.; Makarov, V.G. Birch bark extract as therapy for chronic hepatitis C-A pilot study. Phytomedicine 2011, 18, 807-810. [CrossRef] [PubMed]

23. Dehaen, W.; Mashentseva, A.A.; Seitembetov, T.S. Allobetulin and Its Derivatives: Synthesis and Biological Activity. Molecules 2011, 16, 2443. [CrossRef] [PubMed]

24. Kaplun, A.; Bezrukov, D.A.; Popenko, V.I.; Shvets, V.I. Spherical amorphous nanoparticles from birch bark triterpenoids-A novel type of submicronic vehicle for drug delivery. Russ. J. Biopharm. 2011, 3, 28-40.

25. Wang, H.M.; Şoica, C.M.; Wenz, G. A Comparison Investigation on the Solubilization of Betulin and Betulinic Acid in Cyclodextrin Derivatives. Nat. Prod. Commun. 2012, 7, 1934578X1200700304. [CrossRef]

26. Şoica, C.; Dehelean, C.; Danciu, C.; Wang, H.M.; Wenz, G.; Ambrus, R.; Bojin, F.; Anghel, M. Betulin Complex in $\gamma$-Cyclodextrin Derivatives: Properties and Antineoplasic Activities in In Vitro and In Vivo Tumor Models. Int. J. Mol. Sci. 2012, $13,4992$. [CrossRef] [PubMed]

27. Vorobyova, O.; Deryabina, O.; Malygina, D.; Plotnikova, N.; Solovyeva, A.; Belyaeva, K.; Melnikova, N. Betulin-3,28-diphosphate as a Component of Combination Cytostatic Drugs for the Treatment of Ehrlich Ascites Carcinoma In Vitro and In Vivo Experiments. Sci. Pharm. 2018, 86, 17. [CrossRef]

28. Bureeva, S.; Andia-Pravdivy, J.; Symon, A.; Bichucher, A.; Moskaleva, V.; Popenko, V.; Shpak, A.; Shvets, V.; Kozlov, L.; Kaplun, A. Selective inhibition of the interaction of $\mathrm{C} 1 \mathrm{q}$ with immunoglobulins and the classical pathway of complement activation by steroids and triterpenoids sulfates. Bioorg. Med. Chem. 2007, 15, 3489-3498. [CrossRef]

29. Grishkovets, V.I. Synthesis of triterpenoid sulfates using the $\mathrm{SO}_{3}$-dimethyl sulfoxide complex. Chem. Nat. Compd. 1999, 35, 73-74. [CrossRef]

30. Levdanskii, V.A.; Levdanskii, A.V.; Kuznetsov, B.N. Sulfation of Betulin by Sulfamic Acid in DMF and Dioxane. Chem. Nat. Compd. 2014, 50, 1029-1031. [CrossRef]

31. Dzhil'bert, E.E. Sulfonation of Organic Compounds; Himiya: Moscow, Russia, 1969; p. 415. (In Russian)

32. Caputo, H.E.; Straub, J.E.; Grinstaff, M.W. Design, synthesis, and biomedical applications of synthetic sulphated polysaccharides. Chem. Soc. Rev. 2019, 48, 2338-2365. [CrossRef]

33. Al-Horani, R.A.; Desai, U.R. Chemical Sulfation of Small Molecules-Advances and Challenges. Tetrahedron 2010, 66, 2907-2918. [CrossRef] [PubMed]

34. Spillane, W.; Malaubier, J.-B. Sulfamic Acid and Its N- and O-Substituted Derivatives. Chem. Rev. 2014, 114, 2507-2586. [CrossRef] [PubMed]

35. Kazachenko, A.S.; Vasilieva, N.Y.; Borovkova, V.S.; Fetisova, O.Y.; Issaoui, N.; Malyar, Y.N.; Elsuf'ev, E.V.; Karacharov, A.A.; Skripnikov, A.M.; Miroshnikova, A.V.; et al. Food Xanthan Polysaccharide Sulfation Process with Sulfamic Acid. Foods 2021, 10, 2571. [CrossRef] [PubMed]

36. Kazachenko, A.; Malyar, Y.; Vasilyeva, N.; Fetisova, O.; Chudina, A.; Sudakova, I.; Antonov, A.; Borovkova, V.; Kuznetsova, S Isolation and sulfation of galactoglucomannan from larch wood (Larix sibirica). Wood Sci. Technol. 2021, 55, 1091-1107. [CrossRef]

37. Kazachenko, A.; Vasilyeva, N.; Malyar, Y.; Kazachenko, A. Mathematical Optimization, the Effect of the Catalyst and Solvent on the Process of Starch Sulfation with Sulfamic Acid. In Lecture Notes in Networks and Systems; Springer International Publishing AG: Cham, Switzerland, 2021; pp. 275-282. [CrossRef]

38. Malyar, Y.N.; Vasilyeva, N.Y.; Kazachenko, A.S.; Borovkova, V.S.; Skripnikov, A.M.; Miroshnikova, A.V.; Zimonin, D.V.; Ionin, V.A.; Kazachenko, A.S.; Issaoui, N. Modification of Arabinogalactan Isolated from Larix sibirica Ledeb. into Sulfated Derivatives with the Controlled Molecular Weights. Molecules 2021, 26, 5364. [CrossRef]

39. Kazachenko, A.; Malyar, Y.; Vasilyeva, N.; Borovkova, V.; Issaoui, N. Optimization of guar gum galactomannan sulfation process with sulfamic acid. Biomass Convers. Biorefin. 2021, 1-10. [CrossRef]

40. Kazachenko, A.S.; Akman, F.; Malyar, Y.N.; Issaoui, N.; Vasilieva, N.Y.; Karacharov, A.A. Synthesis optimization, DFT and physicochemical study of chitosan sulfates. J. Mol. Struct. 2021, 1245, 131083. [CrossRef]

41. Kazachenko, A.; Akman, F.; Medimagh, M.; Issaoui, N.; Vasilieva, N.; Malyar, Y.N.; Sudakova, I.G.; Karacharov, A.; Miroshnikova, A.; Al-Dossary, O.M. Sulfation of Diethylaminoethyl-Cellulose: QTAIM Topological Analysis and Experimental and DFT Studies of the Properties. ACS Omega 2021, 6, 22603-22615. [CrossRef] 
42. Kuznetsov, B.N.; Vasilyeva, N.Y.; Kazachenko, A.S.; Skvortsova, G.P.; Levdansky, V.A.; Lutoshkin, M.A. Development of a method for sulfation of ethanolignin of fir wood using sulfamic acid. J. Sib. Fed. Univ. Ser. Chem. 2018, 11, 122-130.

43. Kazachenko, A.S.; Malyar, Y.N.; Vasilyeva, N.Y.; Bondarenko, G.N.; Korolkova, I.V.; Antonov, A.V.; Karacharov, A.A.; Fetisova, O.Y.; Skvortsova, G.P. «Green» synthesis and characterization of galactomannan sulfates obtained using sulfamic acid. Biomass Convers. Biorefin. 2020, 1-10. [CrossRef]

44. Akman, F.; Kazachenko, A.S.; Vasilyeva, N.Y.; Malyar, Y.N. Synthesis and characterization of starch sulfates obtained by the sulfamic acid-urea complex. J. Mol. Struct. 2020, 1208, 127899. [CrossRef]

45. Levdansky, V.; Vasilyeva, N.; Malyar, Y.; Levdansky, A.; Kondrasenko, A.; Kazachenko, A.; Kuznetsov, B. Sulfation of ethanol lignin of abies wood by sulfamic acid in N,N-dimethylformamide medium. Biomass Convers. Biorefin. 2020, 1-8. [CrossRef]

46. Kuznetsov, B.N.; Vasilyeva, N.Y.; Kazachenko, A.S.; Levdansky, V.A.; Kondrasenko, A.A.; Malyar, Y.N.; Skvortsova, G.P.; Lutoshkin, M.A. Optimization of the process of abies ethanol lignin sulfation by sulfamic acid-urea mixture in 1,4-dioxane medium. Wood Sci. Technol. 2020, 54, 365-381. [CrossRef]

47. Kazachenko, A.S.; Levdansky, V.A.; Levdansky, A.V.; Kuznetsov, B.N. Mathematical optimization of the process of birch wood xylan sulfation by sulfamic acid in N, N-dimethylformamide medium. Khimiya Rastit. Syr'ya 2021, 2, 87-94. [CrossRef]

48. Akman, F.; Issaoui, N.; Kazachenko, A. Intermolecular hydrogen bond interactions in the thiourea/water complexes (Thio$(\mathrm{H} 2 \mathrm{O}) \mathrm{n})(\mathrm{n}=1, \ldots, 5):$ X-ray, DFT, NBO, AIM, and RDG analyses. J. Mol. Model. 2020, 26, 161. [CrossRef] [PubMed]

49. Yokoya, M.; Kimura, S.; Yamanaka, M. Urea Derivatives as Functional Molecules: Supramolecular Capsules, Supramolecular Polymers, Supramolecular Gels, Artificial Hosts, and Catalysts. Chem. Eur. J. 2021, 27, 5601-5614. [CrossRef]

50. Civera, C.; del Valle, J.C.; Elorza, M.A.; Elorza, B.; Arias, C.; Díaz-Oliva, C.; Catalán, J.; García Blanco, F. Solvatochromism in urea/water and urea-derivative/water solutions. Phys. Chem. Chem. Phys. 2020, 22, 25165-25176. [CrossRef] [PubMed]

51. Kazachenko, A.S.; Akman, F.; Abdelmoulahi, H.; Issaoui, N.; Malyar, Y.N.; Al-Dossary, O.; Wojcik, M.J. Intermolecular hydrogen bonds interactions in water clusters of ammonium sulfamate: FTIR, X-ray diffraction, AIM, DFT, RDG, ELF, NBO analysis. J. Mol. Liq. 2021, 342, 117475. [CrossRef]

52. Sirviö, J.A.; Ukkola, J.; Liimatainen, H. Direct sulfation of cellulose fibers using a reactive deep eutectic solvent to produce highly charged cellulose nanofibers. Cellulose 2019, 26, 2303-2316. [CrossRef]

53. Sass, R.L. A neutron diffraction study on the crystal structure of sulfamic acid. Acta Crystallogr. 1960, 13, 320-324. [CrossRef]

54. Levdansky, A.V.; Vasilyeva, N.Y.; Kondrasenko, A.A.; Levdansky, V.A.; Malyar, Y.N.; Kazachenko, A.S.; Kuznetsov, B.N. Sulfation of arabinogalactan with sulfamic acid under homogeneous conditions in dimethylsulfoxide medium. Wood Sci. Technol. 2021, 55, 1725-1744. [CrossRef]

55. Malyar, Y.N.; Kazachenko, A.S.; Vasilyeva, N.Y.; Fetisova, O.Y.; Borovkova, V.S.; Miroshnikova, A.V.; Levdansky, A.V.; Skripnikov, A.M. Sulfation of wheat straw soda lignin: Role of solvents and catalysts. Catal. Today 2021, in press. [CrossRef]

56. Vasilyeva, N.Y.; Kazachenko, A.S.; Malyar, Y.; Kuznetsov, B.N. Sulfation of betulin with chlorosulfonic acid in pyridine. J. Sib. Fed. Univ. Chem. 2020, 13, 447-459. [CrossRef]

57. Cabassi, F.; Casu, B.; Perlin, A.S. Infrared absorption and raman scattering of sulfate groups of heparin and related glycosaminoglycans in aqueous solution. Carbohydr. Res. 1978, 63, 1-11. [CrossRef]

58. Krichen, F.; Bougatef, H.; Capitani, F.; Ben Amor, I.; Koubaa, I.; Gargouri, J.; Maccari, F.; Mantovani, V.; Galeotti, F.; Volpi, N.; et al. Purification and structural elucidation of chondroitin sulfate/dermatan sulfate from Atlantic bluefin tuna (Thunnus thynnus) skins and their anticoagulant and ACE inhibitory activities. RSC Adv. 2018, 8, 37965-37975. [CrossRef]

59. Levdanskii, V.A.; Levdanskii, A.V.; Kuznetsov, B.N. Sulfonation of Betulinic Acid by Sulfamic Acid. Chem. Nat. Compd. 2015, 51, 894-896. [CrossRef]

60. Drebushchak, T.N.; Mikhailovskaya, A.V.; Drebushchak, V.A.; Mikhailenko, M.A.; Myz', S.A.; Shakhtshneider, T.P.; Kuznetsova, S.A. Crystalline forms of betulin: Polymorphism or pseudopolymorphism? J. Struct. Chem. 2020, 61, 1260-1266. [CrossRef]

61. Melnikova, N.B.; Malygina, D.S.; Klabukova, I.N.; Belov, D.V.; Vasin, V.A.; Petrov, P.S.; Knyazev, A.V.; Markin, A.V. Betulin-3,28diphosphate. Physico-Chemical Properties and In Vitro Biological Activity Experiments. Molecules 2018, 23, 1175. [CrossRef]

62. Shakhtshneider, T.; Mikhailenko, M.; Drebushchak, V.; Drebushchak, T.; Malyar, Y.; Kuznetsova, S. Effect of ball-milling on the formation of betulin and betulin diacetate composites with polyethylene glycol. Mater. Today Proc. 2019, 12, 78-81. [CrossRef]

63. Yang, D.; Gong, N.; Zhang, L.; Lu, Y.; Du, G. Structural and Computational Study of 4 New Solvatomorphs of Betulin: A Combined X-Ray, Hirshfeld Surface, and Thermal Analysis. J. Pharm. Sci. 2017, 106, 826-834. [CrossRef]

64. Morales, J.E.T.; Pedroso, M.T.C.; Siguenza, J.C.; Villavicencio, C.B. Evaluation of Reactivity (pKa) of Substituted Aromatic Diamines, Monomers for Polyamides Synthesis, via Nuclear Magnetic Resonance, NMR-1H. Chem. Proc. 2021, 3, 8436. [CrossRef]

65. Akman, F. Prediction of Chemical Reactivity of Cellulose and Chitosan Based on Density Functional Theory. Cellul. Chem. Technol. 2017, 51, 253-262.

66. Akman, F.; Kazachenko, A.; Malyar, Y. A density functional theory study of sulfated monolignols: P-Coumaril and coniferyl alcohols. Cellul. Chem. Technol. 2021, 55, 41-54. [CrossRef]

67. Fazilath Basha, A.; Liakath Ali Khan, F.; Muthu, S.; Raja, M. Computational evaluation on molecular structure (Monomer, Dimer), RDG, ELF, electronic (HOMO-LUMO, MEP) properties, and spectroscopic profiling of 8-Quinolinesulfonamide with molecular docking studies. Comput. Theor. Chem. 2021, 1198, 113169. [CrossRef] 
68. Scrocco, E.; Tomasi, J. Electronic Molecular Structure, Reactivity and Intermolecular Forces: An Euristic Interpretation by Means of Electrostatic Molecular Potentials. In Advances in Quantum Chemistry; Löwdin, P.-O., Ed.; Academic Press: Cambridge, MA, USA, 1978; Volume 11, pp. 115-193.

69. Demir, P.; Akman, F. Molecular structure, spectroscopic characterization, HOMO and LUMO analysis of PU and PCL grafted onto PEMA-co-PHEMA with DFT quantum chemical calculations. J. Mol. Struct. 2017, 1134, 404-415. [CrossRef]

70. Akman, F. A comparative study based on molecular structure, spectroscopic, electronic, thermodynamic and NBO analysis of some nitrogen-containing monomers. Polym. Bull. 2021, 78, 663-693. [CrossRef]

71. Muthu, S.; Renuga, S. Vibrational spectra and normal coordinate analysis of 2-hydroxy-3-(2-methoxyphenoxy) propyl carbamate. Spectrochim. Acta Part A Mol. Biomol. Spectrosc. 2014, 132, 313-325. [CrossRef]

72. Janani, S.; Rajagopal, H.; Muthu, S.; Aayisha, S.; Raja, M. Molecular structure, spectroscopic (FT-IR, FT-Raman, NMR), HOMOLUMO, chemical reactivity, AIM, ELF, LOL and Molecular docking studies on 1-Benzyl-4-(N-Boc-amino)piperidine. J. Mol. Struct. 2021, 1230, 129657. [CrossRef]

73. Tahenti, M.; Gatfaoui, S.; Issaoui, N.; Roisnel, T.; Marouani, H. A tetrachlorocobaltate(II) salt with 2-amino-5-picolinium: Synthesis, theoretical and experimental characterization. J. Mol. Struct. 2020, 1207, 127781. [CrossRef]

74. Padmanabhan, J.; Parthasarathi, R.; Subramanian, V.; Chattaraj, P.K. Electrophilicity-Based Charge Transfer Descriptor. J. Phys. Chem. A 2007, 111, 1358-1361. [CrossRef]

75. Domingo, L.R.; Chamorro, E.; Pérez, P. Understanding the Reactivity of Captodative Ethylenes in Polar Cycloaddition Reactions. A Theoretical Study. J. Org. Chem. 2008, 73, 4615-4624. [CrossRef] [PubMed]

76. Fleming, J. Frontier Orbitals and Organic Chemical Reactions. J. Prakt. Chem. 1978, 320, 879-880. [CrossRef]

77. Mondal, S.; Mandal, S.M.; Mondal, T.K.; Sinha, C. Structural characterization of new Schiff bases of sulfamethoxazole and sulfathiazole, their antibacterial activity and docking computation with DHPS protein structure. Spectrochim. Acta Part A Mol. Biomol. Spectrosc. 2015, 150, 268-279. [CrossRef] [PubMed]

78. Parr, R.G.; Pearson, R.G. Absolute hardness: Companion parameter to absolute electronegativity. J. Am. Chem. Soc. 1983, 105, 7512-7516. [CrossRef]

79. Mulliken, R.S. Electronic Population Analysis on LCAO-MO Molecular Wave Functions. I. J. Chem. Phys. 1955, 23, 1833-1840. [CrossRef]

80. Demircioğlu, Z.; Kaştaş, Ç.A.; Büyükgüngör, O. Theoretical analysis (NBO, NPA, Mulliken Population Method) and molecular orbital studies (hardness, chemical potential, electrophilicity and Fukui function analysis) of (E)-2-((4-hydroxy-2methylphenylimino)methyl)-3-methoxyphenol. J. Mol. Struct. 2015, 1091, 183-195. [CrossRef]

81. Rose, M.R.; Lau, S.S.; Prasse, C.; Sivey, J.D. Exotic Electrophiles in Chlorinated and Chloraminated Water: When Conventional Kinetic Models and Reaction Pathways Fall Short. Environ. Sci. Technol. Lett. 2020, 7, 360-370. [CrossRef]

82. Stavber, S.; Jereb, M.; Zupan, M. Electrophilic Iodination of Organic Compounds Using Elemental Iodine or Iodides. Synthesis 2008, 2008, 1487-1513. [CrossRef]

83. Robert, J.; Ouellette, J.D.R. Chapter 13. Electrophilic Aromatic Substitution. Organic Chemistry; Academic Press: London, UK; San Diego, CA, USA, 2018; pp. 375-407. [CrossRef]

84. Profant, V.; Johannessen, C.; Blanch, E.W.; Bouř, P.; Baumruk, V. Effects of sulfation and the environment on the structure of chondroitin sulfate studied via Raman optical activity. Phys. Chem. Chem. Phys. 2019, 21, 7367-7377. [CrossRef]

85. Sagaama, A.; Issaoui, N.; Al-Dossary, O.; Kazachenko, A.S.; Wojcik, M.J. Non covalent interactions and molecular docking studies on morphine compound. J. King Saud Univ. Sci. 2021, 33, 101606. [CrossRef]

86. Kazachenko, A.; Akman, F.; Abir, S.; Issaoui, N.; Malyar, Y.; Vasilieva, N.; Borovkova, V. Theoretical and experimental study of guar gum sulfation. J. Mol. Model. 2021, 27, 5. [CrossRef] [PubMed]

87. Lutoshkin, M.A.; Kazachenko, A.S. Assessment of various density functionals and solvation models to describe acid-base, spectral and complexing properties of thiobarbituric and barbituric acids in aqueous solution. J. Comput. Methods Sci. Eng. 2017, 17, 851-863. [CrossRef]

88. Kazachenko, A.S.; Tomilin, F.N.; Pozdnyakova, A.A.; Vasilyeva, N.Y.; Malyar, Y.N.; Kuznetsova, S.A.; Avramov, P.V. Theoretical DFT interpretation of infrared spectra of biologically active arabinogalactan sulphated derivatives. Chem. Pap. 2020, 74, 4103-4113. [CrossRef]

89. Kazachenko, A.S.; Malyar, Y.N.; Ghatfaoui, S.; Issaoui, N.; Al-Dossary, O.; Wojcik, M.J.; Kazachenko, A.S.; Miroshnikova, A.V.; Berezhnaya, Y.D. A density functional theory calculations of infrared spectra of galactomannan butyl ether. J. Mol. Struct. 2022, 1251, 131998. [CrossRef]

90. Mainreck, N.; Brézillon, S.; Sockalingum, G.D.; Maquart, F.-X.; Manfait, M.; Wegrowski, Y. Rapid characterization of glycosaminoglycans using a combined approach by infrared and Raman microspectroscopies. J. Pharm. Sci. 2011, 100, 441-450. [CrossRef] [PubMed]

91. Akman, F. Spectroscopic investigation, HOMO-LUMO energies, natural bond orbital (NBO) analysis and thermodynamic properties of two-armed macroinitiator containing coumarin with DFT quantum chemical calculations. Can. J. Phys. 2016, 94, 583-593. [CrossRef]

92. Shklyaev, O.E.; Kubicki, J.D.; Watts, H.D.; Crespi, V.H. Constraints on I $\beta$ cellulose twist from DFT calculations of ${ }^{13}$ C NMR chemical shifts. Cellulose 2014, 21, 3979-3991. [CrossRef] 
93. Gerbst, A.; Nikolaev, A.; Yashunsky, D.; Shashkov, A.; Dmitrenok, A.; Nifantiev, N. Theoretical and NMR-based Conformational Analysis of Phosphodiester-linked Disaccharides. Sci. Rep. 2017, 7, 8934. [CrossRef]

94. Issaoui, N.; Rekik, N.; Oujia, B.; Wójcik, M. Anharmonic effects on theoretical IR line shapes of medium strong H(D) bonds. Int. J. Quantum Chem. 2009, 109, 483-499. [CrossRef]

95. Rekik, N.; Issaoui, N.; Oujia, B.; Wójcik, M. Theoretical IR spectral density of H-bond in liquid phase: Combined effects of anharmonicities, Fermi resonances, direct and indirect relaxations. J. Mol. Liq. 2008, 141, 104-109. [CrossRef]

96. Jomaa, I.; Noureddine, O.; Gatfaoui, S.; Issaoui, N.; Roisnel, T.; Marouani, H. Experimental, computational, and in silico analysis of (C8H14N2)2[CdCl6] compound. J. Mol. Struct. 2020, 1213, 128186. [CrossRef]

97. Gatfaoui, S.; Sagaama, A.; Issaoui, N.; Roisnel, T.; Marouani, H. Synthesis, experimental, theoretical study and molecular docking of 1-ethylpiperazine-1,4-diium bis(nitrate). Solid State Sci. 2020, 106, 106326. [CrossRef]

98. Levdansky, V.A.; Levdansky, A.V.; Kuznetsov, B.N. Sulfation of betulin with chlorosulfonic acid in dimethylformamide and dioxane. Russ. J. Bioorg. Chem. 2014, 40, 748-751. [CrossRef]

99. Natalia, Y.V.; Alexander, V.L.; Alexander, S.K.; Galina, P.S.; Boris, N.K. Modification of Sulfated Arabinogalactan with Amino Acids by Ion Exchange Method. J. Sib. Fed. Univ. Chem. 2016, 1, 20-28. [CrossRef]

100. Zagorodni, A. Ion Exchange Materials: Properties and Applications; Elsevier: Amsterdam, The Netherlands, 2006 ; p. 456.

101. Frisch, M.J.; Trucks, G.W.; Schlegel, H.B.; Scuseria, G.E.; Robb, M.A.; Cheeseman, J.R.; Scalmani, G.; Barone, V.; Mennucci, B.; Petersson, G.A.; et al. Gaussian 09; revision C.01; Gaussian, Inc.: Wallingford, CT, USA, 2009.

102. Dennington, R.K.T.; Millam, J. Gauss View, version 5; Semichem Inc.: Shawnee, KS, USA, 2010.

103. Becke, A.D. Density-functional exchange-energy approximation with correct asymptotic behavior. Phys. Rev. A 1988, 38, 3098-3100. [CrossRef]

104. Lee, C.; Yang, W.; Parr, R.G. Development of the Colle-Salvetti correlation-energy formula into a functional of the electron density. Phys. Rev. B 1988, 37, 785-789. [CrossRef]

105. Yanai, T.; Tew, D.P.; Handy, N.C. A new hybrid exchange-correlation functional using the Coulomb-attenuating method (CAM-B3LYP). Chem. Phys. Lett. 2004, 393, 51-57. [CrossRef]

106. Tawada, Y.; Tsuneda, T.; Yanagisawa, S.; Yanai, T.; Hirao, K. A Long-Range Corrected Time-Dependent Density Functional Theory. J. Chem. Phys. 2004, 120, 8425-8433. [CrossRef] 